Portland State University

PDXScholar

2014

\title{
"L'Affaire des Princes": Baroque Architecture and Factional Politics in Regency Paris, 1715-1723
}

Jordan Hallmark

Portland State University

Follow this and additional works at: https://pdxscholar.library.pdx.edu/honorstheses

Let us know how access to this document benefits you.

\section{Recommended Citation}

Hallmark, Jordan, "'L'Affaire des Princes": Baroque Architecture and Factional Politics in Regency Paris, 1715-1723" (2014). University Honors Theses. Paper 96.

https://doi.org/10.15760/honors.94

This Thesis is brought to you for free and open access. It has been accepted for inclusion in University Honors Theses by an authorized administrator of PDXScholar. Please contact us if we can make this document more accessible: pdxscholar@pdx.edu. 
"L'Affaire des Princes":

Baroque architecture and Factional Politics in Regency Paris, 1715-1723

by

Jordan Hallmark

An undergraduate honors thesis submitted in partial fulfillment of the

\author{
requirements for the degree of \\ Bachelor of Arts \\ in \\ University Honors \\ and \\ Art History
}

Thesis Adviser

Jesse Locker

Portland State University

2014 


\section{Introduction: Baroque and Classicism in the Age of Absolutism}

On 17 August 1661, a magnificent fête was held at the newly constructed château de Vaux-le-Vicomte, about thirty miles southeast of Paris, in honor of the French king, Louis XIV, who arrived at the prestigious venue from the nearby château de Fontainebleau. ${ }^{1}$ The king was accompanied by a large retinue of courtiers, who marvelled at the grandeur of the château and the splendor of its formal gardens, which surpassed in magnificence all of the king's own residences. After a tour of the château's richly decorated rooms and the garden's intricate network of parterres and fountains, the guests were treated to a sumptuous dinner, followed by a performance of Molière's comedy-ballet Les Fâcheux, with music by Jean-Baptiste Lully, and a spectacular fireworks show, which illuminated the night sky as flashes of light burst over the château. $^{2}$ This astonishing orchestration of spectacle was put together under the direction of one man, the king's superintendent of finances, Nicolas Fouquet, who sought to use the château de Vaux-Le-Vicomte as a venue in which to pursue his own political ambitions. Work on the château began in 1658, after Fouquet commissioned architect Louis Le Vau to design the edifice, and put painter Charles Le Brun in charge of its interior decoration. ${ }^{3}$ As one of the first private residences in France to be decorated in the exuberant Roman Baroque manner, the château de Vaux-Le-Vicomte (fig. 1) allowed Nicolas Fouquet to present himself as the sole legitimate successor to the kingdom's most power political figure, the king's chief minister, Cardinal Mazarin. Soon after Mazarin's death on 9 March 1661, however, Louis XIV, in a speech that would become famous, declared that he would take personal control of the French state and

\footnotetext{
${ }^{1}$ Anthony Blunt, Art and Architecture in France, 1500-1700, 5th ed. (New Haven, CT: Yale University Press, 1999), 151.

${ }^{2}$ Victor-Lucien Tapié, The Age of Grandeur: Baroque Art and Architecture, trans. A. Ross Williamson, 2nd ed. (New York: Frederick A. Praeger, 1966), 103-4.

${ }^{3}$ Blunt, 147-8.
} 
abolish the position of chief minister. ${ }^{4}$ Convinced that the inexperienced twenty-two year old sovereign was incapable of governing on his own, Fouquet would host his marvelous fête at Vaux-Le-Vicomte in order to impress, as well as to intimidate, the young monarch, and to present himself as an indispensable ally who, as chief minister, would enable the king to realize his dreams of personal glory. But Fouquet's plan backfired. Rather than exciting the admiration of the king, the unparalleled splendor of Vaux-Le-Vicomte inflamed Louis XIV with envy. ${ }^{5}$ Just a few weeks later, Louis XIV had Fouquet arrested and subsequently imprisoned for life in the fortress of Pignerol. ${ }^{6}$ This well-known episode in French monarchical history has often been cited by historians as the event that signaled the birth of royal absolutism in France, forging a highly-centralized system of hereditary monarchy in which there would be no place for any form of competition with the king—-political or otherwise. ${ }^{7}$ Throughout this absolutist regime, which was to endure until the outbreak of the French Revolution in 1789, the French monarchy asserted its political supremacy through the visual language of classicism, a grand, but severe style of architecture and interior design that allowed Louis XIV and his successors to articulate absolutist ideology through a codified system of architectural principles. This classical manner has traditionally been presented in art historical scholarship as the defining feature of France's cultural identity in the seventeenth and eighteenth centuries, and as an aesthetic mode with which the French monarchy could promote its own socio-political ideals of order and reason, employing classicism to define itself in opposition to the capriciousness and irrationality of the

\footnotetext{
${ }^{4}$ Peter Burke, The Fabrication of Louis XIV (New Haven, CT: Yale University Press, 1992), 61-4.

${ }^{5}$ Blunt, 151.

${ }^{6}$ Alan James, The Origins of French Absolutism, 1598-1661, Seminar Studies in History (Abingdon, UK: Routledge, 2013), 87.

7 Ibid., 85-95; Jay M. Smith, The Culture of Merit: Nobility, Royal Service, and the Making of Absolute Monarchy in France, 1600-1789 (Ann Arbor: University of Michigan Press, 1996), 8-9; Anne E. Duggan, Salonnières, Furies, and Fairies: The Politics of Gender and Cultural Change in Absolutist France (Newark: University of Delaware Press, 2005), 165.
} 
Italian Baroque, a style which, because of its use by Fouquet as a visual language with which to compete with, and even eclipse, the monarchy, became associated with disorder, pomposity, and political antagonism. ${ }^{8}$ The Italian Baroque style of architecture and interior decoration, which developed in Rome during the early 1600s before spreading throughout most of Europe in the seventeenth and early eighteenth centuries, was, therefore, as most scholars maintain, prevented from exerting much of an influence on French architecture after $1661 .{ }^{9}$ Yet, rather than being fully eradicated from the architectural history of early modern France, the Italian Baroque style was destined to experience a revival in French architectural and interior design, brought about by the unique social, political, and economic conditions that arose in France during the Regency, an interim political regime that extended from the death of Louis XIV in 1715 until the beginning of Louis XV's personal reign in 1723. A period of relative political decentralization, the years of the Regency saw the formation of different rival factions, whose members used the exuberant Italian Baroque language of architecture and decoration to create magnificent residences with which to compete with the Regent. ${ }^{10}$ By examining the Parisian residences commissioned during this period by the Regent himself, Philippe d'Orléans, and by his two main political rivals, the duc du Maine and the comte de Toulouse, this thesis will demonstrate both the ways in which specific Roman Baroque designs and motifs were used by French architects during the Regency to express the political ambitions of their patrons, as well as how the introduction of these Baroque models was facilitated by the socio-political effects of the affaire des princes, a factional struggle for political influence that took place during the Regency.

\section{The "Affaire des Princes"}

\footnotetext{
${ }^{8}$ See Tapié, "France Between Baroque and Classicism," 86-109.

${ }^{9}$ Ibid.; Blunt, 217.

${ }^{10}$ Rochelle Ziskin, Sheltering Art: Collecting and Social Identity in Early Eighteenth-century Paris (University Park: Pennsylvania State University Press, 2012), 70, 120.
} 
During the eight-year period of the Regency, Louis XIV's nephew, Philippe II, duc d'Orléans, served as Regent of France, governing the kingdom on behalf of the young king, Louis XV, who would fully assume his monarchical powers in 1723 at the age of thirteen. At the time of his birth in 1710, Louis, duc d'Anjou—the future Louis XV—stood far down the line of royal succession. As the youngest great-grandson of the king, Louis XIV, the duc d'Anjou was preceded in the order of succession by his grandfather, le Grand Dauphin; his father, the duc de Bourgogne; and his elder brother, the duc de Bretagne. On 8 March 1712, however, following a devastating outbreak of smallpox, which took the lives of the Grand Dauphin, the duc de Bourgogne, and the duc de Bretagne, among others, the duc d'Anjou became first in line to the throne, receiving the title of Dauphin de France, which he would retain until his succession to the throne as Louis XV on 1 September 1715. Although Louis XV had been first in line to the throne since the death of his father and elder brother in 1712, the young prince was not Louis XIV's only direct descendant. Over the course of his long reign, Louis XIV fathered numerous illegitimate children with his different mistresses, including seven children by FrançoiseAthénaïs, marquise de Montespan, whose tenure as the king's maîtresse en titre had lasted from 1667 until around 1680. In December 1673, Louis XIV issued letters patent to his first two sons by madame de Montespan, three-year old Louis-Auguste and one-year old Louis-César, as well as to their six-month old daughter, Louise-Françoise, which legally legitimized the three children and bestowed noble titles upon each of them. ${ }^{11}$ The legitimization of the king's illegitimate children triggered a major scandal in France, particularly among the nobility, who saw the entry

\footnotetext{
${ }^{11}$ Jacques Bernot, Mademoiselle de Nantes, fille préférée de Louis XIV (Paris: Nouvelles Editions Latines, 2004), 14.
} 
of illegitimately born persons into their own aristocratic ranks as an act of usurpation. ${ }^{12}$ As madame de Montespan was already married at the time of her affair with Louis XIV, who was himself married to the Spanish infante Marie Thérèse of Austria, their children were regarded as the products of a double adultery, the most disgraceful form of bastardom in the eyes of the church, and, according to the social and moral codes of ancien régime France, a permanent mark of impurity. ${ }^{13}$ Yet, in spite of the moral outrage that followed the revelation of their adulterous liaison, the king went on to legitimize all of his children by madame de Montespan, with the exception of their very first child, who had died in 1672, before the first letters patent had been issued. In July 1714, two months after the death of the duc de Berry had established the four year old Dauphin—-the future Louis XV—as the last surviving Bourbon heir to the throne, Louis XIV issued an edict according his two surviving sons by madame de Montespan—Louis-Auguste, duc du Maine; and Louis-Alexandre, comte de Toulouse—-the right to ascend to the throne after the legitimate princes $d u$ sang. ${ }^{14}$ The king then appointed the two legitimized princes, whose new rank placed them just below the princes $d u$ sang and above the rest of the French nobility, to a regency council presided over by the king's legitimate nephew, Philippe II, duc d'Orléans, which was tasked with governing the kingdom in the event that Louis XV had not yet reached the age of majority at the time of his succession to the throne. ${ }^{15}$ When Louis XIV died on 1 September 1715, the duc d'Orléans maneuvered to have himself proclaimed sole regent of the kingdom by the Parlement of Paris, who reversed the king's will and excluded his legitimized sons, the duc

\footnotetext{
${ }^{12}$ Jay Caplan, In the King's Wake: Post-Absolutist Culture in France (Chicago: University of Chicago Press, 1999), 20.

${ }^{13}$ Bernot, 14; Emmanuel Le Roy Ladurie, Saint-Simon and the Court of Louis XIV, trans. Arthur Goldhammer (Chicago: University of Chicago Press, 2001), 96-7.

${ }^{14}$ Ziskin, 119.

${ }^{15}$ Ibid., 119-20.
} 
du Maine and the comte de Toulouse, from the regency government. ${ }^{16}$ Unlike the highly centralized absolutist regime of Louis XIV, however, whose authority had gone virtually unchallenged throughout the entirety of his personal reign, the political powers of the Regent were ambiguous and not absolute, allowing for the emergence of rival factions that would compete with Philippe d'Orléans for control of the Regency. ${ }^{17}$ Among the most important of these competing factions was that of Louis XIV's legitimized children, the 'Old Court' faction, led by two of his legitimized sons, the duc du Maine and the comte de Toulouse. ${ }^{18}$ The political decentralization that took place under the regime of the Regency was paralleled in the cultural sphere by the movement of artistic activity away from the royal palace of Versailles and into the emergent aristocratic milieu of Paris, following the relocation of the government to the capital at the outset of the Regency in $1715 .{ }^{19}$ During this period of factional strife and decentralization in the social, political, and cultural spheres, the urban landscape of Regency Paris became an arena in which the regent, Philippe d'Orléans, and his principal rivals, the duc du Maine and the comte de Toulouse, vied for social and political supremacy, in a factional struggle known as the affaire des princes, by engaging in competitive forms of architectural patronage. By undertaking ambitious architectural and decorative projects, these rival princes constructed magnificent Parisian residences with which each could craft his own royal identity and assert his right to the Regency.

\section{Italian Baroque Architecture: A Historiography}

The principal aim of this thesis is to show how and why Italian Baroque styles of

\footnotetext{
${ }^{16}$ Ibid.; John J. Hurt, Louis XIV and the Parlements: The Assertion of Royal Authority (Manchester, UK: Manchester University Press, 2002), 125.

17 Hurt, 125-7.

${ }^{18}$ Ibid.

${ }^{19}$ Ziskin, 1, 119-20.
} 
architectural and decorative design were adopted in the ambitious building and remodeling projects undertaken by the regent, Philippe d'Orléans, and his rivals—-the duc du maine and the comte de Toulouse — at their respective Parisian residences during the period of the Regency. Therefore, before we can proceed, it is necessary to explain what is meant by the term 'Baroque' in the context of this study. Over the last few decades, a debate has arisen among scholars about the benefits and limitations of the use of the term 'Baroque' in the discipline of art history, triggering a wave of revisionist scholarship that has provided a wide spectrum of approaches and perspectives on the issue. ${ }^{20}$ In 1979, renowned British art historian Anthony Blunt composed a preface to the fourth edition of his seminal art-historical survey, Art and Architecture in France, 1500-1700 (first published in 1953), in which he acknowledged the problematic nature of a group of stylistic terms that appear throughout the text of his book. "On rereading this book thirty years after it was written," he explains, "I became aware of the fact that it is based on the use of certain stylistic terms—-particularly 'Mannerist', 'Baroque', and 'Classical'—which are not defined and the meanings of which are not so obvious now as they seemed to be in the 1940s." ${ }^{21}$ Before the publication of Anthony Blunt's Art and Architecture in France in 1953, the standard usage of the term 'Baroque' in art historical scholarship was still largely based on Swiss art historian Heinrich Wolfflin's application of the term in the late- nineteenth century. In his classic study Renaissance and Baroque (1888), Wolfflin employs the term 'Baroque' to refer to the art of the seventeenth century, whose distinctive formal qualities he contrasts with the 'Classical' characteristics of the Renaissance. ${ }^{22}$ Subsequent generations of art historians were to rely on Wolfflin's method of periodization for formulating their own interpretations of the

\footnotetext{
${ }^{20}$ For a recent group of important revisionist studies of Baroque art and historiography, see Helen Hills, ed., Rethinking the Baroque (Farnham, UK: Ashgate, 2011).

${ }^{21}$ Blunt, ix.

${ }^{22}$ See Heinrich Wölffllin, Renaissance and Baroque, trans. Kathrin Simon (London: William Collins Sons, 1964).
} 
Baroque, a period label they would use as a blanket term for the cultural ethos of seventeenthcentury Europe. In the 1950s and 1960s, however, art historians like Anthony Blunt and Victor Lucien-Tapié published a number of important studies on Baroque art and architecture which abandoned Wolfflin's method of periodization in favor of a more nuanced approach which examined the relationship between style and historical context. ${ }^{23}$

In the preface to the fourth edition of his survey, Anthony Blunt defined the Baroque "as the art which was created in Rome roughly in the period 1620-1680 (and then spread to other countries, including France) in which artists used means which can be summed up in the term 'rhetorical', the aim of which was to strike astonishment and admiration in the spectator.",24 According to the traditional historiography, however, this grand rhetorical style had only a limited influence in France, where, by the second half of the seventeenth century, the visual arts had taken on a more restrained character, in keeping with the tradition of classicism that prevailed at the court of Louis XIV. ${ }^{25}$ In his influential book The Age of Grandeur: Baroque and Classicism in Europe, Victor Lucien-Tapié analyses the various conditions that led to the "triumph of French Classicism" during the personal reign of Louis XIV. ${ }^{26}$ For Lucien-Tapié and a number of other scholars, the turning point came in the first years of Louis XIV's personal reign, with the decision to complete the East façade of the Louvre in a classical style, rather than following the Baroque designs provided by the Italian sculptor and architect, Gian Lorenzo Bernini.. $^{27}$

On 3 December 1665, Gian Lorenzo Bernini, Europe's most celebrated living artist,

\footnotetext{
${ }^{23}$ See Tapié; Blunt; and Anthony Blunt, ed., Baroque and Rococo Architecture and Decoration (New York: Harper and Row, 1978).

${ }^{24}$ Blunt, ix.

${ }^{25}$ Ibid., 217; Tapié, 134-6.

${ }^{26}$ Tapié, 132;

${ }^{27}$ Ibid., 110-31; Blunt, 218-20.
} 
returned to Rome after a troubled sojourn in France, where the sixty-six year old artist had stayed over the last six months at the invitation of the French king, Louis XIV, to design the East façade of the Palais du Louvre. While Bernini's entry into France earlier that year had been met with great excitement, prompting his French hosts to accord him a number of honors traditionally reserved only for the reception of princes, his presence at the French court had soon become the focus of resentment, particularly among French architects, whom the king had passed over for the Louvre commission in favor of a foreigner. ${ }^{28}$ Ultimately, the king would reject all four of Bernini's design proposals (fig. 2), deciding instead to commission a group of French architects to build the East façade of the Louvre in an imposing but severe Classical style (fig. 3). ${ }^{29}$ By choosing the traditional French classical language of order and uniformity over Bernini's innovative style of exuberance and eccentricity, Louis XIV gave architectural expression to his absolutist system of monarchy, and formally banished the Roman Post-Tridentine visual rhetoric with which Nicolas Fouquet had endeavored to surpass the monarchy just four years earlier. Yet, as we will see, Louis XIV's banishment of the Italian Baroque style would only amount to an extended exile. While Gian Lorenzo Bernini would die in Rome on 28 November 1680, frustrated with the failure of his Louvre project, the Roman Baroque style that he and his Roman contemporaries, Francesco Borromini and Pietro da Cortona, in particular, had created through their architectural and decorative projects was to finally traverse the Alps and arrive in Paris during the period of the Regency.

\section{Philippe II, duc d'Orléans and the Palais-Royal}

After the death of Louis XIV's brother Philippe, duc d'Orléans, called Monsieur, on 9 June 1701, the son of the late duke, Philippe II (fig. 4), known hitherto as the duc de Chartres,

\footnotetext{
${ }^{28}$ Blunt, 118-20.

${ }^{29}$ Ibid.
} 
inherited the title of duc d'Orléans and established himself at his father's Parisian residence, the Palais-Royal. Built during the first half of the seventeenth century by Jacques Lemercier for the Cardinal de Richelieu, the Palais-Royal, known as the Palais-Cardinal until its bequest to the crown in 1642, was given to Monsieur in 1692 by the duke's elder brother, Louis XIV. The palace was presented to Monsieur on the occasion of the marriage of the duke's son Philippe II, then known as the duc de Chartres, to the king's illegitimate daughter, Françoise-Marie de Bourbon, along with an enormous dowry awarded by the crown as compensation for the social humiliation imposed on the Orléans family by this mésalliance. ${ }^{30}$ Soon after taking possession of the Palais-Royal in 1701, Philippe II, duc d'Orléans (henceforth referred to as Philippe d'Orléans) continued his father's efforts to modernize the interior of the palace, commissioning Antoine Coypel to paint the ceiling of the new gallery designed by Jules Hardouin-Mansart in the last years of his father's life. ${ }^{31}$ Lemercier's original interiors remained largely unchanged, however, until the period of the Regency, when, following the death of Louis XIV on 1 September 1715, Philippe d'Orléans transferred the government from Versailles to Paris and designated the Palais-Royal as his official residence. On the day after the death of Louis XIV, the regency council to which the king, in his will, had nominated a small circle of princes, including his two illegitimate sons, Louis-Auguste, duc du Maine (fig. 5) and Louis-Alexandre, comte de Toulouse (fig. 6), was dissolved by the Parlement of Paris, which named Philippe d'Orléans sole regent of the kingdom. ${ }^{32}$ While the Regency government of Philippe d'Orléans had many supporters, particularly among the princes légitimes, whose power had been curtailed by the centralized monarchy of Louis XIV, the regime was also under continuing threat from rival

\footnotetext{
${ }^{30}$ Jean-François Bédard, "Political Renewal and Architectural Revival during the French Regency: Oppenord's Palais-Royal," Journal of the Society of Architectural Historians 68, no. 1 (March 2009): 34.

${ }^{31}$ Ibid.

${ }^{32}$ Ziskin, 119-20.
} 
factions, the most powerful of which was the 'Old Court' faction, led by the duc du Maine and the comte de Toulouse, whom the king had legitimized and elevated to the rank of princes $d u$ sang, reserving each of them a place in the line of royal succession. ${ }^{33}$

By promising to restore a number of political powers to the Parlement of Paris that had been revoked under Louis XIV, Philippe d'Orléans succeeded in securing the support of the Parisian magistrates, whose authority he used to exclude the duc du Maine and the comte de Toulouse from the regency government and establish himself as regent in defiance of the king's will. ${ }^{34}$ With the legitimacy of the regent's exclusive control of the government in question, however, Philippe d'Orléans turned to architecture as a means of asserting his authority. The regent commissioned his premier architecte, Gilles-Marie Oppenord, to transform the sober interiors of the Palais-Royal into a series of grand palatial apartments, adorned with sculptural ornament and decorated by such painters as Antoine Coypel, who returned to the Palais-Royal to paint a series of wall-pictures for the gallery. ${ }^{35}$ Although he had begun preparing designs for the remodelling of the palace in 1714 , soon after entering into the service of the duc d'Orléans, Oppenord's renovation of Jules Hardouin-Mansart's gallery was the only project on which work had begun before the beginning of the Regency, and was not completed until $1718 .{ }^{36}$ Work on the remaining interiors, which included the private appartement, the petit appartement, and the salon, as well as the appartements of the duchesse d'Orléans, did not commence until after 1715, and should, therefore, be understood in the context of the socio-political factionalism of Regency

\footnotetext{
${ }^{33}$ Ibid.; Hurt, 125-7.

${ }^{34}$ Hurt, $125-7$.

${ }^{35}$ Katie Scott, The Rococo Interior: Decoration and Social Spaces in Early Eighteenth-Century Paris (New Haven, CT: Yale University Press, 1995), 185-6.

${ }^{36}$ Bédard, 34.
} 
Paris. $^{37}$

Gilles-Marie Oppenord was uniquely suited to create the new palatial interiors that Philippe d'Orléans had envisioned for the Palais-Royal. From 1692 to 1699, Oppenord studied architectural design at the French Academy in Rome under the direction of Matthieu de La Teulière, where he lived as a pensionnaire from $1694 .{ }^{38}$ During his seven-year sojourn, Oppenord followed the traditional academic curriculum, studying the classical monuments of antiquity and the works of Renaissance theorists like Vignola. ${ }^{39}$ But contrary to the pedagogical aims of the French academic system, the subjects that were to have the greatest influence on Oppenord's career as an architect in the service of Philippe d'Orléans were those that he encountered in the course of his own extracurricular studies in the Eternal City, through which the young architect was introduced to the spectacular architectonic culture of Baroque Rome. Unlike his fellow pensionnaires at the French Academy in Rome, whose training was predominantly based on Italian Renaissance architectural theory, Oppenord engaged directly with the architecture of modern Rome, filling his sketchbooks with drawings (fig. 7.1) of works by Rome's three most important seventeenth-century architects: Francesco Borromini (fig. 7.2), Pietro da Cortona, and Gian Lorenzo Bernini. ${ }^{40}$ It is likely, as Gil. R. Smith has argued, that Oppenord was encouraged in his studies of the Roman Baroque by the principe of the accademia di San Luca, Carlo Fontana, who had trained as an architect in the studio of Bernini, whom he was ultimately to succeed as Rome's leading architect. ${ }^{41}$ In 1676, the accademia di San Luca, Rome's premier academy of art and architecture, was merged with the French Academy in

${ }^{37}$ Ibid.

${ }^{38}$ Gil R. Smith, Architectural Diplomacy: Rome and Paris in the Late Baroque (Cambridge: Massachusetts Institute of Technology Press, 1993), 160-1.

${ }^{39}$ Ibid.

${ }^{40}$ Ibid.

${ }^{41}$ Ibid. 
Rome, allowing future French academicians and pensionnaires, like Oppenord, greater access to the visual and academic resources of the Roman academy. ${ }^{42}$

As the architect "on whose shoulders," wrote Rudolf Wittkower, "fell the mantle of the great High Baroque architects," Carlo Fontana played a central role in spreading the Roman Baroque idiom throughout Europe by way of his many pupils. ${ }^{43}$ Many of the most important architects to work outside of Rome in the late seventeenth and early eighteenth centuries passed through the studio of Carlo Fontana, including Nicodemus Tessin the Younger in Stockholm, Johann Bernhard Fischer von Erlach in Vienna and Salzburg, Matthäus Daniel Pöppelmann in Dresden, James Gibbs in London, Oxford, and Cambridge, and Filippo Juvarra in Turin and Madrid. ${ }^{44}$ Conspicuously absent from this list, however, are names of any French architects. While aspiring architects from all over Europe came to Rome to study with Fontana, the French academic system established under Louis XIV ensured that the pensionnaires at the French Academy in Rome followed a strict academic curriculum in accordance with the classical architectural principles promoted by the académie royale d'architecture in Paris, which turned a blind eye to the Roman Baroque tradition of which Fontana was the principal heir. ${ }^{45}$ By maintaining a degree of independence from the French Academy, however, Oppenord could pursue his interests in the architecture and decorative design of modern Rome and absorb the visual language of Bernini, Borromini, and Cortona, as well as the late Baroque styles of living architects like Fontana and Gherardi. ${ }^{46}$ Yet, while Oppenord had successfully resisted the influence of the powerful académie royale throughout his Roman sojourn, its reach would prove

\footnotetext{
${ }^{42}$ Ibid., 17-25.

${ }^{43}$ Rudolf Wittkower, Art and Architecture in Italy, 1600-1750, 6th ed. (New Haven, CT: Yale University Press, 1999), 3:7.

${ }^{44}$ Ibid., 3:9.

${ }^{45}$ Smith, 157-64; Wittkower, 3:7.

${ }^{46}$ Smith, 160-2.
} 
inescapable after Oppenord's return to Paris in 1699. The Roman Baroque manner adopted by Oppenord during his stay in Italy proved at odds with the classical principles upon which France's state-sponsored cultural system was founded, setting him outside of the royal patronage networks through which virtually all major commissions were arranged. ${ }^{47}$

In the last years of Louis XIV's reign, the royal court at the château de Versailles began to lose its monopolizing position at the center of French artistic life. ${ }^{48}$ Faced with the heavy financial burden of the wars of the League of Augsburg (1688-97) and of the Spanish Succession (1701-13), the aging king, whose taste for extravagance had been curtailed in the last years of his life by the sobering influence of his pious, morganatic wife, Françoise d'Aubigné, Marquise de Maintenon, granted very few architectural commissions and made little effort to support the cultural system that he had established earlier in his reign. ${ }^{49}$ During the first fifteen years of the eighteenth century—the last fifteen years of Louis XIV's life and reign—court life at Versailles became increasingly austere, prompting members of the royal court to frequent the private centers of aristocratic culture that operated around the Parisian urban sphere. Paris soon became the new center of aristocratic life in France, triggering an upsurge in building and renovation projects for aristocratic residences in the city. ${ }^{50}$ As these architectural projects were undertaken by the aristocracy, rather than by the crown, the majority of these private commissions were arranged outside of the académie royale d'architecture. ${ }^{51}$ The various artists, architects, and craftsmen involved in the design of these aristocratic townhouses were therefore able to experiment with both modern and classical styles of design, which allowed their patrons to

\footnotetext{
${ }^{47}$ Ibid., 162.

${ }^{48}$ Riskin, 1.

${ }^{49}$ Ibid., 1-5; Scott, 121.

${ }^{50}$ Ziskin, 1.

${ }^{51}$ Ibid.
} 
articulate their own aristocratic identities and compete for social prestige through the design innovations of their respective Parisian residences. It was within this vibrant, but competitive cultural milieu that, in 1713, Gilles-Marie Oppenord was able to secure the patronage of Philippe d'Orléans, after many years of inactivity in France after his return from Rome in 1699.

With the death of Louis XIV in September 1715, and Philippe d'Orléans'subsequent assumption of the Regency, Oppenord suddenly found himself as the chief architect to the most powerful man in France. Oppenord's position as the regent's premier architecte left him charged with one of the most important architectural commissions in France at the time-the renovation of the Palais Royal. Unlike the the majority of domestic architectural undertakings pursued in Paris during the first quarter of the eighteenth century, Oppenord's project for the Palais-Royal, as we have seen, concerned the renovation of a palace, rather than a maison or hotel particulier. With the re-emergence of Paris as the center of French aristocratic life in the early eighteenth century, these different residential building types and their relation to established social orders and distinctions became central to French civil and domestic architectural practice. ${ }^{52}$ For while the classical architectural principles promoted at the académie royale d'architecture, although still central to French architectural theory, were no longer governing the work of French architects like Oppenord, the rules of social decorum that maintained social distinctions through fixed codes of conduct and self-presentation would prove much more difficult to break. By the early eighteenth century, the term convenance had been adopted by French architectural theorists to denote this concept of social decorum as applied to architecture and decoration, a concept which prioritized the appropriate architectural expression of the social orders of eighteenthcentury France over the correct application of the classical orders as systematized in Renaissance

\footnotetext{
${ }^{52}$ Scott, 103-5.
} 
architectural theory. ${ }^{53}$ Writing in the second-half of the eighteenth century, French architectural theorist Jacques-François Blondel explains in his Cours d'architecture that in order for a building to have convenance, both its external architectonic arrangement and its interior decorative elements needed to perfectly correspond to the objective that prompted the building's construction. $^{54}$

For the aristocratic patrons of Regency Paris, the objective of domestic architectural construction was to give visible architectonic and decorative form to their respective social ranks. In his chapter on residential buildings, Blondel states that an architect must look to the rank of his patron in order to determine the appropriate style of decoration to use for the design of a private residence. "For example," writes Blondel, "the residences designed for an heir to the throne, a prime minister, and a Chancellor of France, respectively, may proclaim [their owners' ranks] in different ways; each [needing] to display a certain degree of magnificence . . . 56 Therefore, as a matter of convenance, the palace of the Regent had to be decorated on a scale of magnificence unparalleled among French princely and aristocratic residences. To achieve this, Oppenord needed to renovate the interiors of the Palais-Royal in a style that would set his patron's Parisian residence apart from those of even the most prestigious French princes, and, most importantly, from the roughly contemporaneous architectural undertakings of the regent's principal rivals — the duc du Maine and the comte de Toulouse. Set against the background of this factional rivalry, these issues of convenance take on a political dimension that will prove critical to our analysis of Oppenord's renovations at the Palais Royal.

\footnotetext{
${ }^{53}$ Ibid., 109.

54 “'On dit qu'un bâtiment a de la convenance, lorsqu'on a remarqué que sa disposition extérieure et les principales parties de sa décoration sont absolument relatives à l'objet qui a donné lieu à ériger l'édifice . . .” Jacques-François Blondel, Cours d'architecture, ou Traité de la décoration, distribution et construction des bâtiments contenant les leçons données en 1750, et les années suivantes (Paris: Desaint, 1771), 1: 381.

55 "Le rang du propriétaire est donc la source où l'Architecte doit puiser le genre de sa décoration.” Ibid., 2: 236. 56 Ibid.
} 
The obvious choice of style for the expression of political authority in early modern France was the style Louis XIV, the French royal style par excellence epitomized in the grands appartements of the château de Versailles. But Oppenord needed to be cautious about suggesting too close a connection between the person of the regent and the authority of the monarchy. After the sudden and unexpected deaths of Louis XIV's three successive heirs in April 1712, many contemporaries suspected that Philippe d'Orleans had been responsible for poisoning the king's descendants in order to move himself further up the line of royal succession. ${ }^{57}$ While all three deaths were determined to be the result of an outbreak of smallpox, Philippe d'Orléans, even after becoming Regent, continued to be regarded with suspicion by his enemies, particularly the 'Old Court' faction, who feared an attempt to poison the young Louis XV in the hope of placing the House of Orléans on the French throne. ${ }^{58}$ Thus, Oppenord's renovations at the Palais-Royal needed to surpass the private residences of the French nobility in their magnificence, while employing a different language of architecture and decorative design that distinguished the socio-political identity of the regent from the dynastic identity of Louis XV and his Bourbon predecessors. This need for a new stylistic language of architectonic and decorative magnificence presented Oppenord with an opportunity to draw on his Roman training, an architectural background that had previously been an obstacle to his professional success in France. By adapting the exuberant architectonic forms and dynamic spatial effects of Bernini and Borromini, and their respective Italian followers, to the domestic interiors of the Palais-Royal, Oppenord was able to present the regent as a powerful sovereign, while using a foreign language of princely representation devoid of French dynastic iconography.

\footnotetext{
${ }^{57}$ Louis de Rouvroy, duc de Saint-Simon, Mémoires complets et authentiques du duc de Saint-Simon sur le siècle de Louis XIV et la Régence: 1691-1723, ed. Adolphe Chéruel (Paris: Hachette, 1857), 10:134.

${ }^{58}$ Ibid.; Hurt, 127.
} 
In 1784, Oppenord's interior decorations in the Palais-Royal were demolished on the orders of Philippe d'Orléans' descendant, Louis-Philippe-Joseph d'Orléans, who wished to renovate the palace in accordance with the prevailing classical taste of the late-eighteenth century. ${ }^{59}$ In spite of the tragic fate that befell the refurbished interiors of the Regent's grand appartement, a considerable number of visual records survive, allowing us to study various aspects of Oppenord's interior decorative schemes for the Palais-Royal. In examining these drawings, etchings, and other graphic materials, the close relationship of Oppenord's designs for the Palais-Royal to Roman Baroque architecture and decoration becomes immediately apparent. Oppenord's designs for two rooms in particular, the Galerie d'Énée and the Salon d'Angle, display recognizable references to specific works of Roman Baroque architecture and decoration that Oppenord would have certainly seen during his stay in the Eternal City about two decades earlier. The first of these rooms to undergo renovation by Oppenord was the Galerie d'Énée, which, as we have seen, did not figure within Lemercier's original spatial arrangement for the Palais-Royal, but was first constructed for Philippe d'Orléans' father by Jules Hardouin-Mansart in the last years of the seventeenth century. ${ }^{60}$ While no drawings survive to indicate the original appearance of the Galerie d'Énée, it seems fair to assume that the gallery designed by HardouinMansart, the most important proponent of the style Louis XIV, had nothing of the Baroque exuberance that would characterize Oppenord's gallery design. ${ }^{61}$ The gallery takes its name, the Galerie d'Énée, or Gallery of Aeneas, from the gallery's pictorial decoration, which was begun by Antoine Coypel several years before Oppenord's involvement, and consisted of a series of

\footnotetext{
${ }^{59}$ Bédard, 31.

${ }^{60}$ Ibid., 34.

${ }^{61}$ Ibid., 34-6.
} 
scenes from Virgil's Aeneid. ${ }^{62}$ While Coypel's ceiling paintings were completed in 1705, his sequence of wall-pictures were not commissioned for the gallery until 1715, after Oppenord had begun his renovation work on the decorative program of the room, and were completed by 1718. ${ }^{63}$ The most important surviving visual record of Oppenord's design for the Galerie d'Énée is an etching from Blondel's Cours d'architecture, showing the North end of the gallery (fig. 8). ${ }^{64}$ As Jean-François Bédard has noted, the decoration of the North end wall represents Oppenord's most serious departure from the French classical manner practiced by the gallery's first architect, Jules Hardouin-Mansart. ${ }^{65}$ Oppenord, like the great Baroque architects of seventeenth-century Rome, bases his design on a common classical motif, in this instance a triumphal arch, which he then animates through various layers of sculptural ornament and decorative figures. ${ }^{66}$ The interaction of these decorative layers with the architectural substructure of the interior forms a dynamic, integrated composition, whose scenographic presentation transforms its static classical core into an exuberant Baroque drama. Oppenord's design for the North end of the gallery combines architectonic and ornamental motifs from two of Rome's most spectacular works of High Baroque decoration, both designed by Gian Lorenzo Bernini for the Vatican Apostolic Palace. The most important of these Baroque creations, Bernini's Scala Regia (fig. 9), appears to have been Oppenord's primary source of inspiration for the design of the North end of the gallery. Oppenord's design sets the front elevation of Bernini's magnificent barrel vaulted stairwell into the North-end of the Galere d'Énée, forming a shallow niche, which is flanked by two colossal piers and faced with a large rectangular mirror, corresponding to the

\footnotetext{
${ }^{62}$ Ibid.

${ }^{63}$ Scott, $185-6$.

${ }^{64}$ Bédard, 36.

${ }^{65}$ Ibid.

${ }^{66}$ Ibid.
} 
open entry arch of the Scala Regia. The lateral rectangular piers and central mirrored niche of the North end are crowned by an entablature, forming the triumphal arch substructure of the wall, which acquires a strong vertical emphasis and impressive sense of grandeur through the classical order of the arch's front elevation. In Oppenord's design, the free-standing Scamozzi Ionic columns of Bernini's colonnade are replaced by a tetrastyle elevation of fluted Corinthian pilasters, which articulate the vertical divisions between the three bays of the arch and the outer limits of the lateral piers. The most distinctly Roman Baroque feature of Oppenord's design for the North end of the gallery is undoubtedly the pair of winged Victories set in the center of the arch's entablature. ${ }^{67}$ Suspended directly above the mirrored niche of the arch, the winged figures hold up an elaborate cartouche bearing the ducal coat of arms of the maison d'Orléans, which is crowned by a ducal coronet and set within a large scallop shell. ${ }^{68}$ As several scholars have already noted, Oppenord's group of winged Victories appears to derive from the pair of winged figures of Fame adorning the arched entrance to Bernini's Scala Regia (see fig. 9), who carry a large escutcheon, embellished with the arms of Pope Alexander VII Chigi and crowned by the papal tiara and crossed keys of St. Peter. ${ }^{69}$ In his design for the North end of the Galerie d'Énée, Oppenord combined this winged figural group derived from the Scala Regia with another Berninian motif, a swag of fictive drapery, rendered in marble or stucco, which hangs from the cartouche at the center of the entablature over the upper corners of the mirror. This decorative motif was first employed by Bernini in 1656 in his renovation of the Sala Ducale (fig. 10), a small antechamber in the Vatican Palace that Bernini had enlarged by combining the space with an adjacent room. As the two rooms were individually vaulted, Bernini was unable to create a

\footnotetext{
67 Ibid.

${ }^{68}$ Scott, 186.

${ }^{69}$ Bédard, 36; Jean-Marie Pérouse de Montclos, Histoire de l'architecture française: De la Renaissance à la Révolution (Paris: Mengès, 1989), 344-6.
} 
visual impression of spatial unity by simply eliminating the dividing wall. In order to transform this pair of adjoining rooms into a single spatial and decorative unit, Bernini installed a tremendous canopy of stucco drapery over the dividing line, replacing the solid wall that once separated the two spaces, with a fictive curtain joining them together. Modeled by Bernini's gifted studio assistant Antonio Raggi, this spectacular canopy of drapery is held aloft by a team of putti, a theatrical invention that Oppenord would employ in his design for the Palais-Royal, substituting Bernini's group of winged infants for a pair of Victories. ${ }^{70}$ As we have seen, Oppenord's Victories are likely based on Bernini's winged figures of Fame at the Scala Regia, but another possible source, as Fiske Kimball has noted, is the pair of Angels kneeling at the entrance to Francesco Borromini’s Cappella Spada (fig. 11) in the church of San Girolamo della Carità in Rome. ${ }^{71}$ Designed by Borromini in 1660, the two Angels in the Cappella Spada also support a large piece of drapery, which Oppenord, whose sketchbooks are filled with drawings after Borromini's works, likely knew from his time in Rome. ${ }^{72}$

Although Blondel's engraving of the North end of the gallery is the only extant visual record of Oppenord's decorative scheme, the various first-hand descriptions of the Galérie d'Énée that survive allow us to form a more complete picture of the gallery interior. With the publication of his Nouvelle description de la ville de Paris in 1725, just a few years after Oppenord's remodeling project was completed, Germain Brice issued one of the earliest printed descriptions of the Galérie d'Énée. "La nouvelle galerie à l'extrémité de cet appartement," Brice records:

\footnotetext{
${ }^{70}$ Wittkower, 2:179n22.

${ }^{71}$ Fiske Kimball, The Creation of the Rococo (New York: Norton Library, 1964), 116.

72 Bédard, 33; For more on Oppenord's drawings of works by Borromini, see Joseph Connors, "Borromini in Oppenord's Sketchbooks," in Ars naturam adiuvans: Festschrift für Matthias Winner, ed. Victoria V. Flemming and Sebastian Schütze (Mainz am Rhein: P. von Zabern, 1996), 598-612.
} 
est revêtue d'un lambris décoré d'une magnifique architecture, en pilastre composites, rudentez, qui portent une corniche, dont la frise est ornée de consoles couplées, entre lesquelles sont des trophées d'un tres belle invention. Ce qui embellit infiniment toute cette decoration, c'est la riche dorure qui brille partout avec une abondance extrême. L'entrée de cette galerie est accompagnée de deux colonnes du même ordre qui y regne par tout pour la distinguer du reste. ${ }^{73}$

Brice's description of the Galérie d'Énée conjures up an image of architectural grandeur and decorative richness that is typically identified with the architecture and interior decoration of seventeenth-century Rome. While several of the decorative motifs recorded by Brice would have been known to Oppenord from the Galérie des Glaces at the château de Versailles and from a handful of other French galleries, like those at the Louvre or at Saint-Cloud, Oppenord's principal source of inspiration for the design of the Galérie d'Énée was more likely a Roman gallery, such as the galleria at Palazzo Colonna (fig. 12). By producing a design that combined architectural elements and decorative motifs from some of Rome's most spectacular works of seventeenth-century Baroque palace design, and set them within an Roman-style galleria, modeled after one of the grandest galleries in the Eternal City, Oppenord provided his patron, the duc d'Orléans, with a space in which he could assert his authority as Regent of the kingdom.

After completing the Galérie d'Énée in 1718, Oppenord began the remodelling of the neighboring room, the salon, which connected the gallery to the Regent's grands appartements. Like his design for the Galérie d'Énée, Oppenord's decorative scheme for the salon was to transform Jules Hardouin-Mansart's Louis XIV-style classical interior into an Italian Baroque decorative ensemble, creating a magnificent space with which Philippe d'Orleans could assert his authority as Regent. But whereas Oppenord had effected this stylistic transformation in the gallery by simply implementing a new decorative program, the transformation of the Regent's

\footnotetext{
${ }^{73}$ Germain Brice, Nouvelle description de la ville de Paris, et de tout ce qu'elle contient de plus remarquable (Paris: J. M. Gandouin, 1725), 1:241-42.
} 
salon would involve the architectural reconfiguration of the entire space into a distinctly Italian form. Completed by 1721, Oppenord's salon, the Salon d'Angle (fig. 13), takes its name from the profusion of different angles formed by the room's intricate floor plan, the hybrid shape of which is completely unique in the history of Western architecture. In spite of the plan's formal singularity, however, Oppenord's inventive manipulation of space and geometric forms in his design for the Salon d'Angle, although unprecedented in the architecture of France, lies entirely in the free spirit of Borromini's complex geometric approach to architectural design. Fortunately, even though the Salon d'Angle was subjected to the same tragic fate as the Galérie d'Énée in 1784, the influence of the Borrominian Baroque language of architecture on Oppenord's floor plan for the Regent's salon can be thoroughly examined, thanks to the large number of surviving drawings by Oppenord for the Salon d'Angle that are today divided between the Musée Carnavalet and the Bibliothèque nationale de France in Paris, and the Cooper-Hewitt, National Design Museum in New York. ${ }^{74}$ Oppenord's design for the floor plan of the Salon d'Angle (fig. 14), executed in pen and black ink on a sheet preserved in the Musée Carnavalet, was likely inspired by the complex geometric plan of Borromini's Sant'Ivo alla Sapienza in Rome (fig. 15), a church that Oppenord sketched multiple times over the course of his Roman sojourn (see fig. 7.1). For the plan of Sant'Ivo, Borromini began with two equilateral triangles, which he overlapped to form a regular hexagram. Then, by changing the $60^{\circ}$ angles of one triangle into convex arcs, and substituting concave semi-circles for the corners of the other triangle, Borromini transformed the hexagram into a hexagonal plan bounded by six recesses, creating an undulating rhythmic sequence in which, as Rudolf Wittkower observes, "recesses of a concave shape and recesses with slanting walls and convex endings alternate and face each other across

\footnotetext{
${ }^{74}$ Bédard, 31.
} 
the space." ${ }^{, 75}$ For the floor plan of the Salon d'Angle, Oppenord was to follow a similar approach, drawing on the Baroque spatial planning of Borromini's Sant'Ivo to turn the traditional rectangular plan of the salon into a dynamic Italian Baroque interior. By setting convex curves in the center of the North and South sides of the rectangular plan and replacing the East and West ends of the salon with pairs of converging diagonals connected by concave endings, Oppenord was able to evoke the undulating rhythm of Borromini's Baroque creations.

The Roman Baroque stylistic characteristics of the Salon d'Angle can be observed, not only in Oppenord's intricate floor plan, but also in his vaulted two-story design for the room, which he recorded in a sectional elevation, executed in ink and watercolor and preserved at the Cooper Hewitt, National Design Museum in New York (see fig. 13). ${ }^{76}$ Known as a salon à l'italienne, due to the appearance of these types of two-story rooms in various sixteenth-century designs for Venetian villas by Andrea Palladio, the space is composed of a lower vaulted chamber with an oculus, surmounted by a second vaulted chamber, with a balustrade surrounding the open space of the oculus. ${ }^{77}$ In addition to providing a space in which musicians could perform while remaining hidden from view, the second chamber also served to illuminate the salon with its concealed windows. ${ }^{78}$ Although attempts have been made to link Oppenord's salon to various seventeenth-century French models, namely to Louis Le Vau's designs for several salons à l'italienne, the two-story design of the Salon d'Angle, like the decorative scheme of the Galérie d'Énée, was based on different seventeenth-century Roman models. ${ }^{79}$ According to Gil R. Smith, the two-story arrangement of the Salon d'Angle was likely inspired

\footnotetext{
${ }^{75}$ Wittkower, 2:46.

${ }^{76}$ Bédard, 31, 46.

${ }^{77}$ Robert W. Berger, Antoine Le Pautre: A French Architect of the Era of Louis XIV (New York: New York University Press, 1969), 26-7.

${ }^{78}$ Smith, 162.

${ }^{79}$ Bédard, 39; Berger, 27-9.
} 
both by Carlo Fontana's baptistery in St. Peter's basilica (1692-98) and by Antonio Gherardi's cappella di Santa Cecilia (fig. 16) in the church of San Carlo ai Catinari (1691-1700). ${ }^{80}$ By adapting the magnificent designs of these sacred spaces, which Oppenord would have likely encountered during his time in Rome, to suit the political agenda of Philippe d'Orléans, Oppenord was able to assert the authority of his patron with the rhetorical force of the Roman Baroque.

\section{Louis-Auguste de Bourbon, duc du Maine and the Palais de l'Arsenal}

Although the revocation of Louis XIV's testament by the Parlement of Paris in September 1715 deprived the duc du Maine and the comte de Toulouse of the sovereign powers accorded them in the provisions of their father's will, the two legitimized princes were nevertheless allowed to hold the governmental offices that the late king had provided for them. ${ }^{81}$ In his will, Louis XIV had named the oldest of his two legitimized sons, Louis-Auguste de Bourbon, duc du Maine, superintendent of Louis XV's education, a position that entitled the duc du Maine and his wife, Louise-Bénédicte de Bourbon-Condé, duchesse du Maine, to reside in the Tuileries Palace in Paris, where the young king had his living quarters. ${ }^{82}$ In August 1718 , however, the duc du Maine was removed from his office as superintendent of the king's education, and he and his wife were forced to leave their apartments at the Tuileries Palace. ${ }^{83}$ While the duc and duchesse du Maine had considerable land holdings outside of Paris, and were the proprietors of two magnificent country residences, the château de Sceaux and the château de Clagny, the couple needed to remain in Paris if they were to maintain a presence in the political arena. After the termination of his functions as superintendent of the king's education, the duc du

\footnotetext{
${ }^{80}$ Smith, 162.

${ }^{81}$ Ziskin, 119-20.

${ }^{82}$ Hurt, 161.

${ }^{83}$ Ziskin, 175.
} 
Maine took residence at the palais de l'Arsenal, the Parisian residence attached to the office of the grand-master of the Artillery, which the duc du Maine had held since his appointment to the position by Louis XIV in $1694 .{ }^{84}$ In 1710 , Louis XIV made the office of the grand-master into a hereditary title, which the duc du Maine would transfer to his son, Louis Charles de Bourbon, comte d'Eu. ${ }^{85}$ Just months before the death of Louis XIV on 1 September 1715, the duc du Maine embarked on an extensive renovation of the palais de l'Arsenal, with the full financial backing of the king. ${ }^{86}$ The king had elevated the duc du Maine, together with the comte de Toulouse, to the rank of prince du sang, and now sought to renovate the outmoded palais de l'Arsenal in a manner suitable to his son's new princely rank. ${ }^{87}$

The man engaged to transform the historic structure of the Arsenal into a princely residence was Germain Boffrand, a French architect of international renown who had performed a similar architectural transformation a few years earlier, between 1709 and 1713, with his renovation of the Petit-Luxembourg for the mother of the duchesse du Maine, Anne de Bavière. ${ }^{88}$ Although he never travelled to Italy, Boffrand, like his contemporary Gilles-Marie Oppenord, was highly influenced by modern Italian architecture, and many of his designs come closer to the Baroque inventions of Bernini and Fontana than to the work of his French contemporaries. ${ }^{89}$ In 1690, Boffrand was appointed conservator of drawings in the collection of the battiments du roi, providing him access to a wide range of architectural drawings, including Gian Lorenzo

\footnotetext{
${ }^{84}$ Jean-Pierre Babelon, "Le palais de l'Arsenal à Paris: étude architecturale et essai de répertoire iconographique critique," Bulletin Monumental 128 (1970): 273-4.

${ }^{85}$ Ibid., 275.

${ }^{86}$ Ibid., 273-4.

${ }^{87}$ Bruno Pons, "Germain Boffrand et le Décor Intérieur," in Germain Boffrand, 1667-1754: L'aventure d'un architecte indépendant, ed. Michel Gallet and Jörg Garms (Paris: Herscher, 1986), 207.

88 Jörg Garms, "Boffrand," in Gallet and Garms, 34-9.

${ }^{89}$ Christopher Tadgell, "France," in Blunt, Baroque and Rococo, 133-4.
} 
Bernini's projects for the Palais du Louvre. ${ }^{90}$ These unexecuted designs for the east façade of the Louvre, which Bernini submitted to Louis XIV's finance minister and surintendant des batîments, Jean-Baptiste Colbert, in 1665, were to have a major influence on Boffrand's architectural projects, beginning with his work for Léopold I, duc de Lorraine, who appointed Boffrand as his premier architecte in $1711 .^{91}$ Although the area was occupied by the French at various times during the War of the Spanish Succession (1701-1713), the duchy of Lorraine was an independent principality at the time of Boffrand's service as premier architecte. The ducal sovereigns of Lorraine, by whom Boffrand was employed, presided over a sophisticated court at Nancy, which, in spite of its proximity to the French kingdom, maintained much stronger ties with the Habsburg Empire than with France. The relative political autonomy enjoyed by the duchy of Lorraine also allowed for a degree of cultural independence, presenting Boffrand with an opportunity to work with modern Italian forms and motifs beyond the reach of the académie royale d'architecture in Paris.

Although Boffrand designed a number of different residences for Léopold I, it is his unexecuted second design for the château de La Malgrange in Jarville (fig. 17), outside of Nancy, that best shows his engagement with the architectural and decorative design practices of seventeenth and early eighteenth-century Italy. Intended as a pleasure palace, or maison de plaisance, Boffrand began work on the project in 1711 and produced two different designs, the second of which was never carried out. ${ }^{92}$ The design is most likely based, as many scholars have observed, on the plan of a Viennese country residence designed by Johann Bernhard Fischer von

\footnotetext{
${ }^{90}$ Garms, 23.

${ }^{91}$ Ibid., 71.

${ }^{92}$ Ibid., 85-6.
} 
Erlach, a pupil of Carlo Fontana, in the 1690s for Count Althan. ${ }^{93}$ The design of Count Althan's country residence was likely introduced to Boffrand by his patron Leopold I, who enjoyed close ties with the Viennese court, or by the Bolognese architect Francesco Galli Bibiena, who had been working in Vienna before arriving in Nancy in 1708 to design an opera theater for the duke of Lorraine. ${ }^{94}$ The designs of Boffrand and Fischer von Erlach have essentially the same ground plan, a St. Andrew's cross, whose four diagonal arms serve as wings and connect to a central rotunda, which is flanked on either side of its longitudinal axis by a series of irregularly-shaped rooms occupying the space between each pair of diagonal wings. Although located near Vienna, Fischer von Erlach's palace design is in the architectonic language of the Italian Baroque, a language that the Austrian-born architect absorbed during his training at the studio of Carlo Fontana and through his study of works by Bernini and Borromini. The convex façades of both Fischer von Erlach and Boffrand ultimately derive from a Berninian invention-Bernini's first project for the east façade of the Louvre (see fig. 2). ${ }^{95}$ But whereas the dramatic curvilinear motion of Bernini's project is disrupted in Fischer von Erlach's design by a rectangular portico that projects out from the center of the convex façade, Boffrand's design, on the other hand, preserves Bernini's spectacular undulating order of pilasters, which conform to the convexity of the façade and accentuate its sense of sinuous movement.

The Louvre projects were not the only architectural designs by Gian Lorenzo Bernini that were to have a major influence on the work of Germain Boffrand. In 1699, the Roman publisher Domenico de' Rossi published a new edition of Giovanni Battista Falda's Nuovo Teatro delle Fabriche, et Edificii, In Prospettiva di Roma moderna, containing a series of etchings by

\footnotetext{
${ }^{93}$ Ibid., 86-7; Tadgell, 134.

${ }^{94}$ Garms, 78.

${ }^{95}$ Tadgell, 133-4.
} 
Alessandro Specchi of the great buildings of modern Rome. ${ }^{96}$ Rossi's widely circulated publication introduced the Baroque monuments of seventeenth-century Rome to the rest of Europe, allowing architects like Germain Boffrand, to study the works of Bernini, Borromini, and Cortona without travelling to the Eternal City. ${ }^{97}$ Bernini’s Palazzo Chigi-Odescalchi, recorded in an etching by Specchi in the 1699 edition of de' Rossi's Nuovo Teatro (fig. 18), had a particularly strong influence on the work of Boffrand, and served, as I will argue, as a model for the façade designed by Boffrand for the palais de l'Arsenal. Designed by Gian Lorenzo Bernini in 1664 for the nephew of Pope Alexander VII, Cardinal Flavio Chigi, the great façade of the Palazzo Chigi-Odescalchi was first used by Boffrand as a model for his architectural designs during his residence at the court of Léopold I in Nancy. In 1712, while in the service of the duc de Lorraine, Boffrand began work on a grand hôtel particulier in Nancy for the prince de Craon, the highest ranking member of the ducal court of Léopold I. Composed of three parts, a central avant-corps and two receding lateral wings, the façade of the Hôtel de Craon (fig. 19), which overlooked the place de la Carrière in Nancy, was closely modeled on the tripartite façade of Bernini's Palazzo Chigi-Odescalchi, maintaining its series of colossal Corinthian pilasters, but reducing the seven-bay distribution of the seventeenth-century prototype to an even width of six bays. ${ }^{98}$ Boffrand's innovate use of Italian Baroque forms made him a favorite at the ducal court of Lorraine, and would soon catch the eye of the French king, Louis XIV, who would wish to enlist his services for the renovation of the Arsenal in Paris.

In the same year that he was commissioned to build the hôtel de Craon in Nancy, Germain Boffrand was appointed architect of the Arsenal, the seat of the Grand Master of the

\footnotetext{
${ }^{96}$ Alexander Grönert, "Domenico de' Rossi," in Architectural Theory: From the Renaissance to the Present (Cologne: Taschen, 2003) 150.

${ }^{97}$ Ibid.

${ }^{98}$ Garms, 102
} 
Artillery in Paris, by Louis XIV. ${ }^{99}$ Three years after his appointment, in the early months of 1715, Boffrand was charged with carrying out a series of major transformations at the palais de l'Arsenal, a massive architectural undertaking financed by the king on behalf of his recently legitimized son, Louis-Auguste de Bourbon, duc du Maine. ${ }^{100}$ Although the palais de l'Arsenal had been in the possession of the duc du Maine since his appointment to the position of grand master of the artillery by the king in 1694, the Parisian site was too far from the royal court at Versailles to have served as the duke's primary residence. Shortly after the death of Louis XIV on 1 September 1715, however, Paris would regain its role as the social, cultural, and political center of the French kingdom. ${ }^{101}$ Within just days of the king's death, Philippe d'Orléans succeeded in nullifying the provisions of the king's will. After proclaiming himself sole regent of the kingdom, Philippe d'Orléans moved the government back to Paris, and took up residence at the Palais-Royal, now two years into Oppenord's renovation project, which, as we have already observed, was to transform the regent's ancestral dwelling into a splendid Roman Baroque-style palace. With the remodeling work on the Palais-Royal underway, the duc du Maine prepared to mount a challenge to the monarchical authority claimed by Philippe d'Orléans, and asserted through the decorative program that Oppenord had planned for the regent's Parisian residence. By transforming the outmoded building of the Arsenal into a magnificent palace in the Roman Baroque style, the duc du Maine sought to appropriate the Italian architectural language of Philippe d'Orléans' palatial residence in order to articulate his own rival political ambitions, using the Parisian public sphere as a stage on which to present himself as the rightful regent of the kingdom. In his competitive struggle for control of the regency, the duc du Maine conceived

\footnotetext{
${ }^{99}$ Ibid., 41.

${ }^{100}$ Babelon, 274.

${ }^{101}$ Ziskin, 1.
} 
of the palais de l'Arsenal as a central component of his political opposition to the regime of the duc d'Orléans. Unlike the regent, whose renovation project for the Palais-Royal was to leave Jacques Lemercier's original façades intact, the duc du Maine was to charge Boffrand, not only with remodeling multiple rooms in the Arsenal, but also with erecting a new façade on the side of the quai Morland, overlooking the river Seine. Thus, while the Roman Baroque language in which the duc d'Orléans' political authority found artistic expression could only speak to those with access to the regent's grand appartement at the Palais-Royal, the prominent position of Boffrand's façade, by contrast, would allow the duc du Maine's message of political opposition to the Regency government to reach all levels of society. Boffrand's design for the new façade of the palais de l'Arsenal (fig. 20), the surviving drawings for which are preserved in the Bibliothèque nationale, is based on the façade of Bernini's Palazzo Chigi-Odescalchi, which, as we have seen, served as the model for the façade of Boffrand's hôtel de Craon in Nancy. The façade of Boffrand's Arsenal retains the tripartite arrangement of Bernini's design, with a central avant-corps, flanked by two receding lateral wings. Unlike the avant-corps of the hôtel de Craon, however, which Boffrand reduced to six bays, the avant-corps of the Arsenal façade retains Bernini's seven-bay scheme. Although Boffrand's design for the Arsenal façade lost some of the grandeur of Bernini's original façade by eliminating its colossal order of Corinthian pilasters, the magnificent balustrade crowning Boffrand's design for the Arsenal, based on the Baroque-style balustraded rooflines of the Palazzo Chigi-Odescalchi and other seventeenthcentury Roman palazzi, gave imposing architectonic expression to the duc du Maine's political aspirations. Decorated with stone cannons, alluding to the duc du Maine's role as Grand Master of the Artillery, the balustrade of the Arsenal's Roman Baroque style façade was given a martial iconographic program that Boffrand was to reprise for the decorative scheme of the palace 
interior. $^{102}$

Boffrand's remodeling work on the interior of the palais de l'Arsenal involved the installation of two sets of apartments, one reserved for the duc du Maine, and the other for his wife, Anne-Louise-Bénédicte de Bourbon-Condé, duchesse du Maine. ${ }^{103}$ While the apartments of the duc and duchesse du Maine have undergone many transformations since the Regency, rendering them useless in the context of this study, a small number of extant drawings by Boffrand for the salon of the palais de l'Arsenal allow us to examine the decorative program devised by Boffrand for the most important room in the palace. For the salon of the palais de l'Arsenal (fig. 21), Boffrand translated the Roman Baroque architectural style and martial iconographic programme of his design for the façade of the Arsenal into the language of interior decoration, creating an impressive space in which he could further promote the political agenda of the duc du Maine. Just as he had based his design for the façade of the Arsenal on the exterior of a Roman Baroque palazzo, Boffrand would again use an Italian Baroque model as the basis of his decorative scheme for the salon. The surviving drawings by Boffrand for the salon show the elevations of three of the room's four walls: two long lateral walls, each faced with three round arches; and, at the far end of the room, a chimney-piece surmounted by a round-arched mirror, similar the the north-end wall of Oppenord's Galérie d'Énée at the Palais-Royal. Each of one of the six arches in the salon is flanked by a pair of thin wall panels, decorated with cannon motifs modeled on the stone cannons adorning the balustrade of the palace façade. The wall panels extend from the floor up to an architrave, which surrounds almost the entire room, dividing the semi-circular top sections of the arches from the lower recturalar segments. By placing a running cornice just above the arcades, Boffrand enclosed the semi-circular sections of the arches within

\footnotetext{
102 Garms, 42.

${ }^{103}$ Pons, 207-8.
} 
a large frieze, which he decorated with a magnificent series of sculptural groups, executed in the Italian Baroque manner, illustrating various scenes from the military campaigns of Alexander the Great. ${ }^{104}$ In both its iconographic program, which associated the duc du Maine with Alexander the Great, one of Louis XIV's personal emblems, and in its Baroque decorative scheme, which appears to derive from Pietro da Cortona's sale dei pianeti in the Palazzo Pitti in Florence (fig. 22), Boffrand's salon staged a powerful demonstration of political opposition, on behalf of the duc du Maine, to the established authority of the Regent.

\section{The Galérie Dorée at the hôtel de Toulouse}

At around the same time that Germain Boffrand was involved with remodeling the palais de l'Arsenal, the duc du Maine's younger brother, the comte de Toulouse, was undertaking a series of renovations at this own Paris residence, the hôtel de Toulouse. ${ }^{105}$ Acquired by the comte de Toulouse in 1713, the hôtel de Toulouse was built between 1635 and 1640 by the architect François Mansart for the Marquis de la Vrillière, a wealthy French statesman. ${ }^{106}$ Although his renovation project was less extensive than those of his brother, the duc du Maine, and his political rival, Philippe d'Orléans, the comte de Toulouse was nevertheless to commission the French decorator François-Antoine Vassé to create one of the most magnificent Roman Baroque style interiors outside of the Italian peninsula. Built to surpass the Baroque gallery that Oppenord had designed for the Regent, Vassé's Galérie Dorée (fig. 23) at the hôtel de Toulouse, completed around 1718, recalls the galleria of the Palazzo Colonna in Rome in its plan and architectonic configuration, but features an ever richer baroque decorative program incorporating diverse sculptural forms inspired by late seicento stucco decorations like Filippo Carcani’s Cappella

\footnotetext{
${ }^{104}$ Ibid., 209.

${ }^{105}$ Scott, $186-8$.

${ }^{106}$ Ibid.
} 
Lancellotti (fig. 24) in the church of San Giovanni in Laterano Yet, in spite of the opulent gilding and decorative richness of Vassé's Galérie Dorée, the space failed to articulate a clear oppositional message against the regime of the Regent. ${ }^{107}$ Whereas Boffrand's decorative program at the palais de l'Arsenal had used the military victories of Alexander the Great to emphasize the political agenda of the duc du Maine, the Galérie Dorée of the comte de Toulouse lacked a discernable political theme. In her book, The Rococo Interior (1995), Katie Scott argues that this "absence of thematic reinforcement between the various figurative elements of the room diminished the iconographic impact of Vassé's ornament and denied it the heroic leverage latent in the Arsenal solution." ${ }^{108}$ Unlike the duc du Maine, for whom the Italian Baroque style served above all as a language of political ideology, the comte de Toulouse used the Baroque style of architecture to present an image of power, but one that avoided engaging in competition with the Regency government. The comte de Toulouse was likely aware of Nicolas Fouquet's use of Baroque architecture several decades earlier to compete with the established political regime, and hoped to avoid the same fate at all costs. The comte de Toulouse's prudence paid off. He would continue to play an active political role within the Regent's administration, and maintain his noble rank just below the princes du sang and above the rest of the French nobility, in the spite of his affiliation with the 'Old Court' faction. ${ }^{109}$ On the other hand, the comte de Toulouse's brother, the duc du Maine, would not be so fortunate. Aware of the political threat that the palais de l'Arsenal would pose if completed in the exuberant Roman Baroque style conceived by Germain Boffrand, Philippe d'Orléans used his authority as Regent to seize the

\footnotetext{
${ }^{107}$ Ibid., 191.

${ }^{108}$ Ibid.

${ }^{109}$ Caplan, 35.
} 
funds that Louis XIV had left the duc du Maine to finance the renovation project. ${ }^{110}$ In August 1718, the Regent removed the duc du Maine from his position as superintendent of Louis XV's education. Later that year, after the duc du Maine and his wife were implicated in a conspiracy to depose the Regent, the duc and duchesse du Maine were sent into exile for a year. ${ }^{111}$ Although the renovation of the Arsenal was never to enable the duc du Maine to replace the duc d'Orléans as regent, the series of major political and legal events that took place in connection with these architectural projects reveals the important political role that the Italian Baroque style of architecture and decoration played in Regency Paris.

\section{Conclusion: Grand Goût or Goût Moderne?}

The interior decorative schemes designed by Gilles-Marie Oppenord and FrançoisAntoine Vassé for the Palais-Royal and hôtel de Toulouse, respectively, were given their first serious scholarly treatment in 1943 by the American architectural historian Fiske Kimball in his groundbreaking study, The Creation of the Rococo. Kimball's book, which charts the development of the Rococo genre of decoration and interior design in eighteenth-century France, treats the Rococo, or style Louis $X V$, as the culmination of an evolutionary process, whose sequence it attempts to trace and interpret through formal analysis. Employing this formalist approach, Kimball identifies a variety of Italian Baroque forms and stylistic features in the designs of Oppenord and Vassé, particularly in the galleries they designed for their respective patrons: Oppenord's Galérie d'Énée for the duc d'Orléans and Vassé's Galérie Dorée for the comte de Toulouse. Yet, while Kimball acknowledges the influence of Italian Baroque models on the work of Oppenord and Vassé, and even cites specific architectural and decorative models from seventeenth-century Rome that these two French architects seem to have imitated, he

\footnotetext{
${ }^{110}$ Babelon, 274.

${ }^{111}$ Ibid., 273-4.
} 
rejects the idea that either of the two were working in an Italian Baroque style. ${ }^{112}$ According to Kimball, both Oppenord and Vassé "adhere to the established scheme of the French interior as opposed to anything Italian, both adopt essentially the scheme of [Pierre] Lepautre, with a linear surface treatment emphasizing height, and modifying the geometric, tectonic frame by arabesque elements of progressively freer curvature."113 Given the strong formal and stylistic similarities that we have observed between Vassé and Oppenord's designs for eighteenth-century French domestic interiors and the Baroque church and palace designs of various seventeenth-century Roman architects, it may seem surprising that Kimball identifies both architects as followers of an established tradition of French architecture. The French style of design with which Kimball associates the work of Vassé and Oppenord, however, is not the French classical style promoted by the académie royale d'architecture, but rather a "new French scheme," Kimball explains, “.. . far removed from the academic system hitherto prevailing in France." ${ }^{114}$ Kimball devotes the second part of his book, under the title of "Genesis," to introducing this new idiom of French interior design. According to Kimball, the new French scheme was the creation of the architect Pierre Lepautre, who, in 1699, was named dessinateur des batîments du roi, placing him in charge of the interior decorations of the king's palaces and other royal commissions. ${ }^{115}$ From 1699 until the death of Louis XIV in 1715, Lepautre redesigned a number of important interiors at such royal residences as Marly and Versailles, where, as Kimball argues, he freed the seventeenth-century classical interior of its rigid architectonic structure and introduced a variety of swirling decorative motifs, creating an ornamental style of design that would become known as the goût moderne, or modern style, the term used in the eighteenth-century to refer to the style

\footnotetext{
112 Kimball, 116.

${ }^{113}$ Ibid., 122.

${ }^{114}$ Ibid., 110.

${ }^{115}$ Ibid., 62-3.
} 
we know today as the Rococo. ${ }^{116}$ It was thus the decorative work of Lepautre that, according to Kimball, "initiated the whole evolution of the rococo," a sequence of stylistic phases which Kimball examines in the third part of his book, appropriately entitled "Evolution." ${ }^{117}$ For Kimball, the protagonists of the first phase of the Rococo, the style régence, which extends from 1715 to 1730, are Gilles-Marie Oppenord and François-Antoine Vassé, the architects who Kimball presents as the successors of Pierre Lepautre. " "From the accession of Louis XV," writes Kimball, "coincident with the death of Lepautre, the lead was held by Oppenord, appointed architect of the Regent, and by Vassé ... [who] pursued the line struck out by Lepautre."119 This line of stylistic evolution links Vassé and Oppenord, not only to Pierre Lepautre, but also to the leading designers of Kimball's second phase of Rococo decoration, the style pittoresque, establishing Vassé and Oppenord among the major pioneers of the goût moderne. ${ }^{120}$

Kimball was not, however, the first to associate the decorative work of Oppenord and Vassé with the style pittoresque of French designers like Nicolas Pineau and Juste-Aurèle Meissonier. In December 1754, Charles-Nicolas Cochin, a noted art critic and engraver, and a vocal detractor of the goût moderne, published an article in the Mercure de France in which he criticized the Rococo, condemning what he saw as the style's overabundance of ornament and disregard for classical principles of order and proportion. ${ }^{121}$ A few months later, in February 1755, Cochin published a follow-up article, an ironic defense of the Rococo style, in which he identifies Gilles-Marie Oppenord as one of France's leading ornemanistes, together with Nicolas

\footnotetext{
${ }^{116}$ Ibid., 109-11.

117 Ibid., 224.

${ }^{118}$ Ibid.

${ }^{119}$ Ibid.

${ }^{120}$ Ibid.

${ }^{121}$ Scott, 258.
} 
Pineau and Juste-Aurèle Meissonier. ${ }^{122}$ Speaking from the perspective of a Rococo designer, Cochin writes: "Le fameux Oppenord nous servit dans commencements avec beaucoup de zéle. . . . Il se servit abondamment de nos ornaments favoris, et les mit en crédit. Il nous est même encore d'une grande utilité, et nous pouvons compter au nombre des notres ceux qui le prennent pour modèle."123 A few decades later, in his Vie des fameux architectes, depuis la Renaissance des arts of 1787, a compilation of biographies of architects from the Renaissance to the eighteenth century, art critic Antoine-Nicolas Dézallier d'Argenville takes Cochin's critique a step further, identifying Oppenord, not with a specific stylistic movement, like the Rococo, but rather with what architectural historian Jean-François Bédard identifies as an "ideologically driven movement," which grouped together a number of architects that Dézallier d'Argenville and his fellow neoclassical critics held responsible for drawing French architecture into a period of decadence. ${ }^{124}$ "Le succès de ses productions " writes Dézallier d'Argenville in his entry on Oppenord, “a presque opéré en France la décadence de l'Architecture. Les Guarini, les Meissonier, et les Germain, également amateurs des formes bizarres et contournées, auraient repolongé la France dans la barbarie, sans les efforts de quelques artistes éclairés qui n'ont jamais perdu de vue les vrais principes de l'Architecture." ${ }^{25}$ Dézallier d'Argenville groups Oppenord together with this diverse circle of designers, including the French Rococo silversmith Thomas Germain and the Italian Baroque architect Guarino Guarini, not on the basis of formal or stylistic similarities between the artists' works, but rather on account of Oppenord's failure to conform to

\footnotetext{
122 Ibid., 259-61.

${ }^{123}$ Charles-Nicolas Cochin, "Lettre à M. l'abbé R***," Mercure de France (February 1755), quoted in Kimball, 147.

124 Jean-François Bédard, Decorative Games: Ornament, Rhetoric, and Noble Culture in the Work of Gilles-Marie Oppenord (1672-1742) (Newark: University of Delaware Press, 2011), 14.

${ }^{125}$ Antoine-Nicolas Dézallier d'Argenville, Vies Des Fameux Architectes Depuis La Renaissance Des Arts, Avec La Description De Leurs Ouvrages (Paris: Debure, 1787), 1:438-9.
} 
the principles of classical architecture, earning him a place alongside Germain, Guarini, Meissonier, and other stylistically disparate artists, on the cultural blacklist of late eighteenthcentury France. Published in 1787, a mere two years before the outbreak of the French Revolution, Dezallier d'Argenville' s Vie des fameux architectes was more than just a collection of biographies; it was also, as Bédard has argued, a work of "neoclassical propaganda." "126 In a recent article published in the Journal of the Society of Architectural Historians (March 2009), Bédard challenges the traditional view of Oppenord as one of the founders of the French Rococo style, a view that he says is inconsistent with the visual evidence of Oppenord's designs for the Palais-Royal. "Despite Oppenord's eighteenth-century detractors," writes Bédard, "who saw him as a master of the French rocaille- the florid decorative manner best represented by the work of Nicolas Pineau and Juste-Aurèle Meissonier-little in the architect's work at the Palais-Royal supports that opinion."127 Bédard traces the origins of Oppenord's association with the Rococo to the Neoclassical critics of the late eighteenth century, whose ideologically driven polemics he discredits through his formal analysis of Oppenord's designs for the Palais-Royal, revealing the architect's use of motifs derived, not from eighteenth-century ornemanistes, but rather from seventeenth-century architects like Gian Lorenzo Bernini. ${ }^{128}$

While this scholarly reassessment would free Oppenord from the stylistic label imposed upon him by his Neoclassical critics, Bédard's interpretation of the designs for the Palais-Royal had still failed to escape the ideological framework that lay at the center of the opposition between the 'grand goût' classique and the goût moderne. In spite of having identified a number of different Roman Baroque motifs in his designs, Bédard associates Oppenord, not with the

\footnotetext{
${ }^{126}$ Bédard, "Political Renewal and Architecture Revival," 33.

${ }^{127}$ Ibid., 30.

${ }^{128}$ Ibid., 36.
} 
seventeenth-century Roman style of Bernini or Borromini, but instead with the French classical manner, known as the style Louis XIV. ${ }^{129}$ In his essay, Bédard maintains that the Roman Baroque motifs in Oppenord's designs for the Palais-Royal were not directly inspired by Italian models, but rather were derived from seventeenth-century decorative schemes at the château de Versailles, realized for Louis XIV by architects and designers like Louis Le Vau, Jules Hardouin-Mansart, and Charles Le Brun, who had been influenced by Roman architecture. ${ }^{130}$ "With his revocation of the Italianate style of Louis XIV's residence in the Palais-Royal's appartement de parade,” writes Bédard, “. . . Oppenord fulfilled his client's program. He transformed the Palais-Royal into a surrogate Versailles." ${ }^{\prime 31}$ Rather than challenging the binary ideological framework by which the Neoclassical critics of the late eighteenth century had associated Oppenord, and various other designers whose works had come to symbolize the excesses of the ancien régime, with the "decadent" goût moderne, Bédard, instead, retains this binary opposition between the classical grand goût, and the rococo goût moderne, drawing on the former's association with monarchical power to maintain that Philippe d'Orléans had instructed Oppenord to remodel the Palais-Royal in the style Louis XIV in order to "stress dynastic continuity." 132 Not only is this interpretation inconsistent with the visual evidence of Oppenord's designs, which, as we have seen, derive from specific seventeenth-century Roman models, but it also fails to take into account the impact of the affaire des princes, the political rivalry between Philippe d'Orléans' and the duc du Maine and the comte de Toulouse, on Oppenord's design of the Palais-Royal. While Bédard acknowledges that Philippe d'Orléans commissioned Oppenord to remodel his Parisian residence in order to maintain the legitimacy of

\footnotetext{
${ }^{129}$ Ibid., 33.

${ }^{130}$ Ibid.

${ }^{131}$ Ibid., 31 .

${ }^{132}$ Ibid.
} 
his regime in the face of political opposition, he makes no mention of the architectural projects undertaken in Paris at the same time by his political rivals. ${ }^{133}$ By examining these architectural projects together, both with regard to their use of Italian Baroque architectural elements and in relation to the affaire des princes, this thesis has show the way in which the competitive ethos that emerged during the period of the Regency gave rise to an architectural style that was neither Classical nor Rococo. Drawing on the architectural innovations of seventeenth-century Rome, these architects involved with these three projects used an Italian artistic creation to respond to the political needs of their French patrons.

${ }^{133}$ Ibid., 30. 


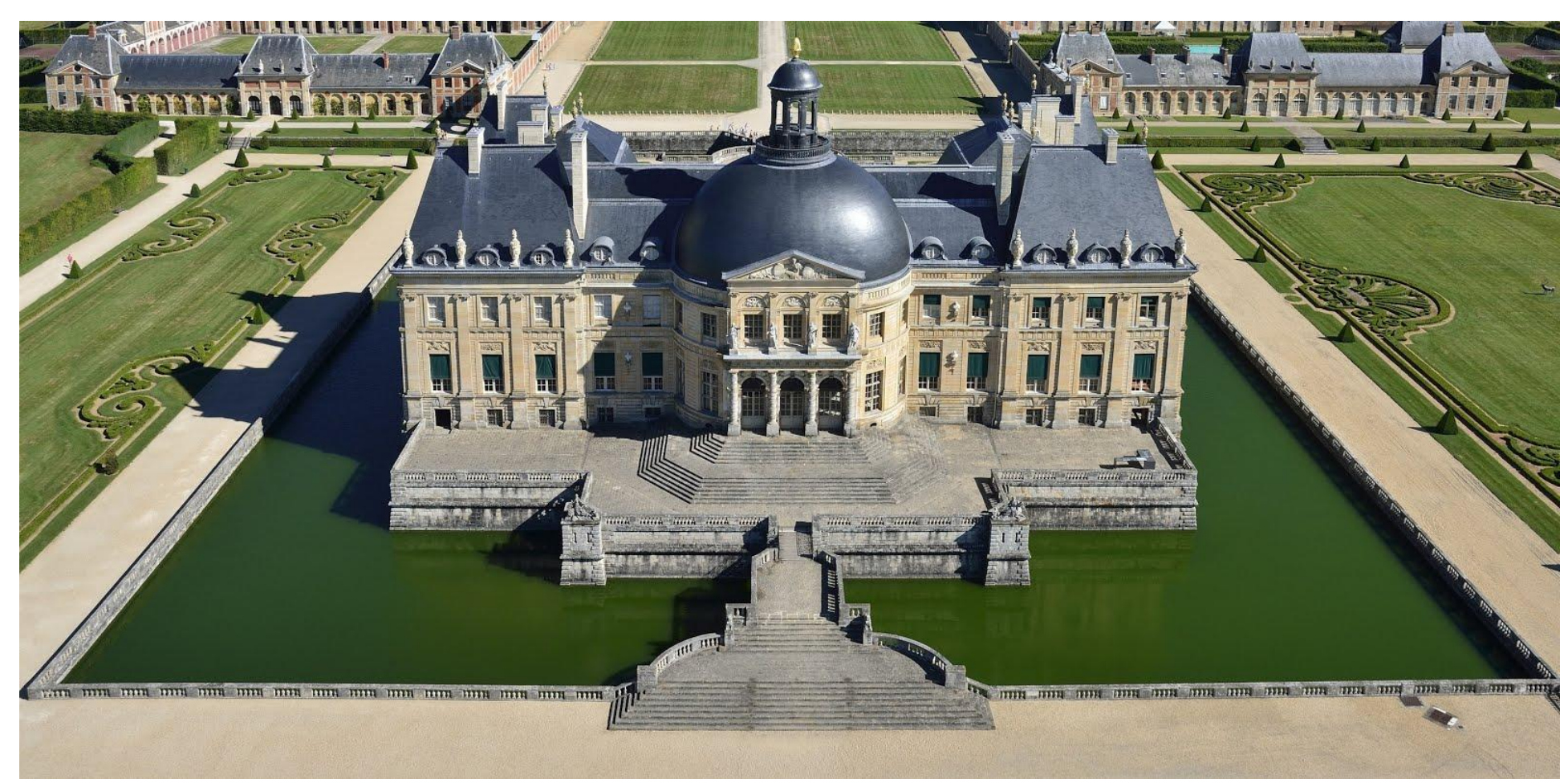

Figure 1. Louis Le Vau (architect), Charles Le Brun (painter-decorator), and André Le Nôtre (garden designer). Château de Vaux-le-Vicomte, Maincy, France. 1657-1661.

Figure 2. Gian Lorenzo Bernini. First project for the East façade of the Louvre. 1664. Pen and brown ink with brown wash on paper. Musée du Louvre. Paris.

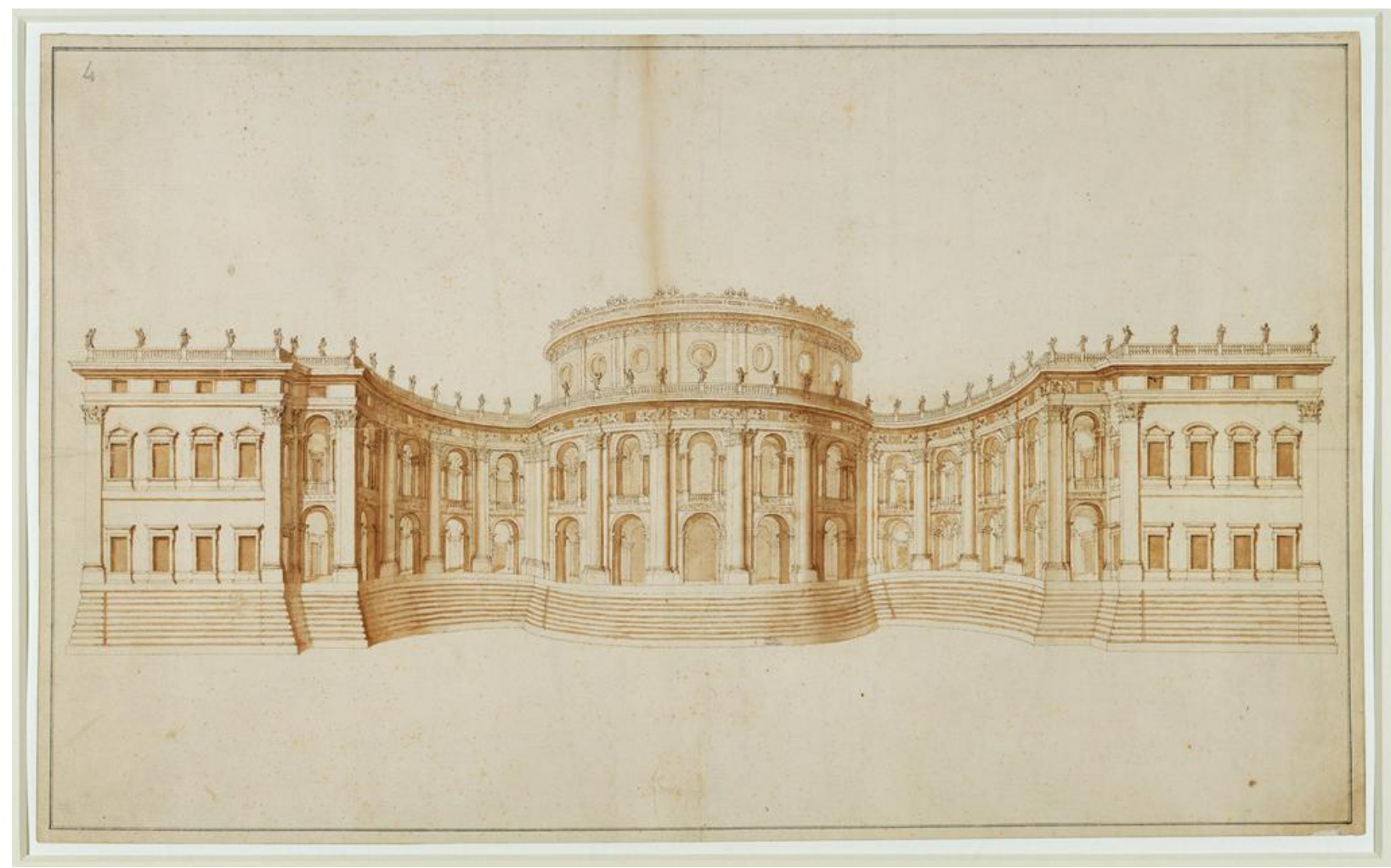




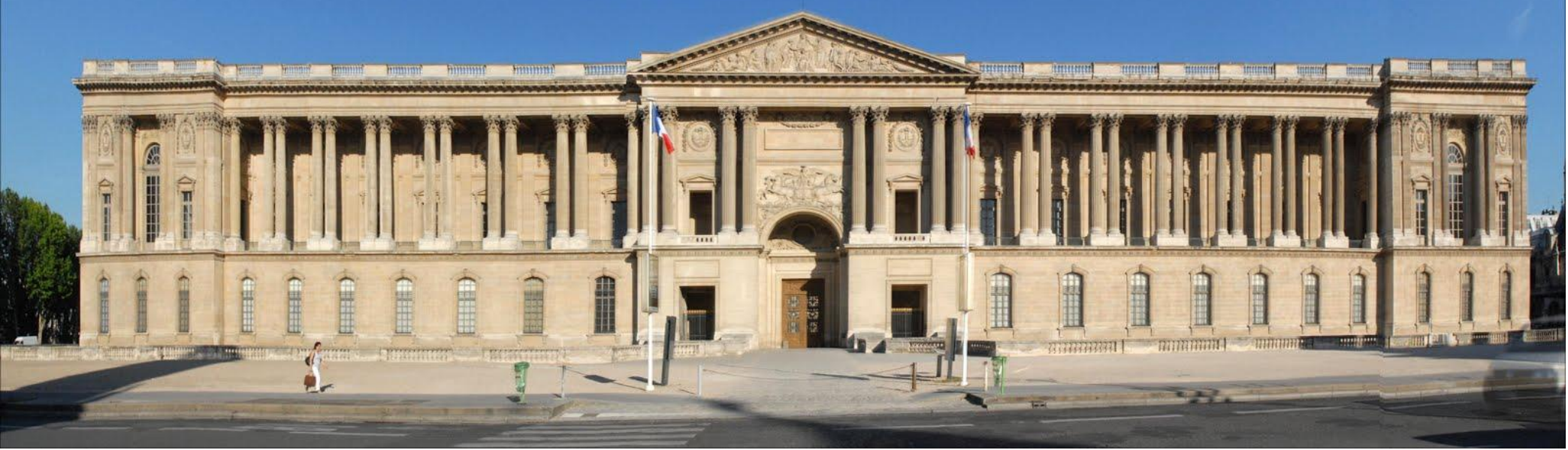

Figure 3. Claude Perrault, Louis Le Vau, and Charles Le Brun. East façade of the Louvre, Paris. 1667-1670.

Figure 4. Jean-Baptiste Santerre. Portrait of Philippe II, duc d'Orléans. ca. 1710-1717. Oil on canvas. Birmingham Museum and Art Gallery. Birmingham, UK.

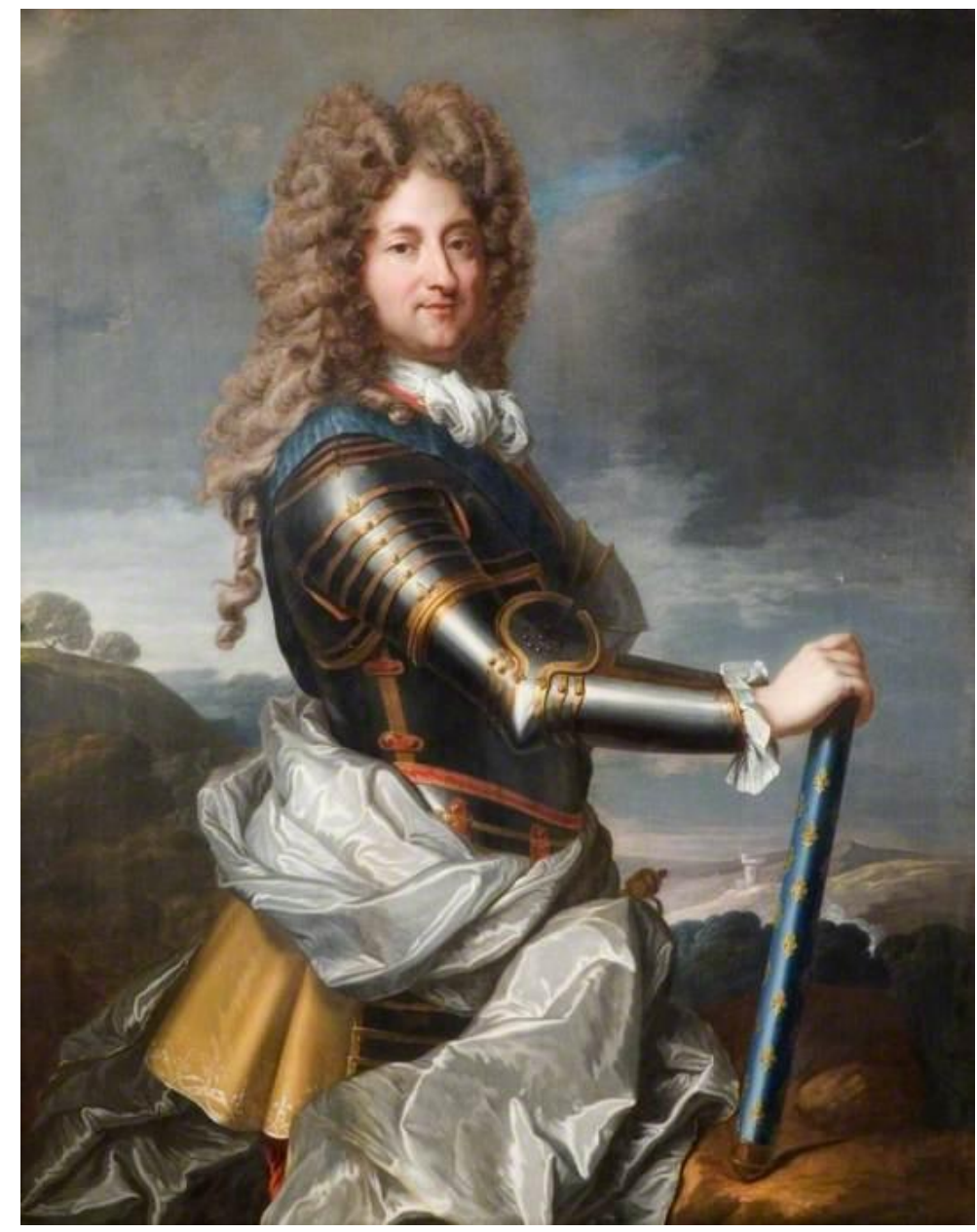




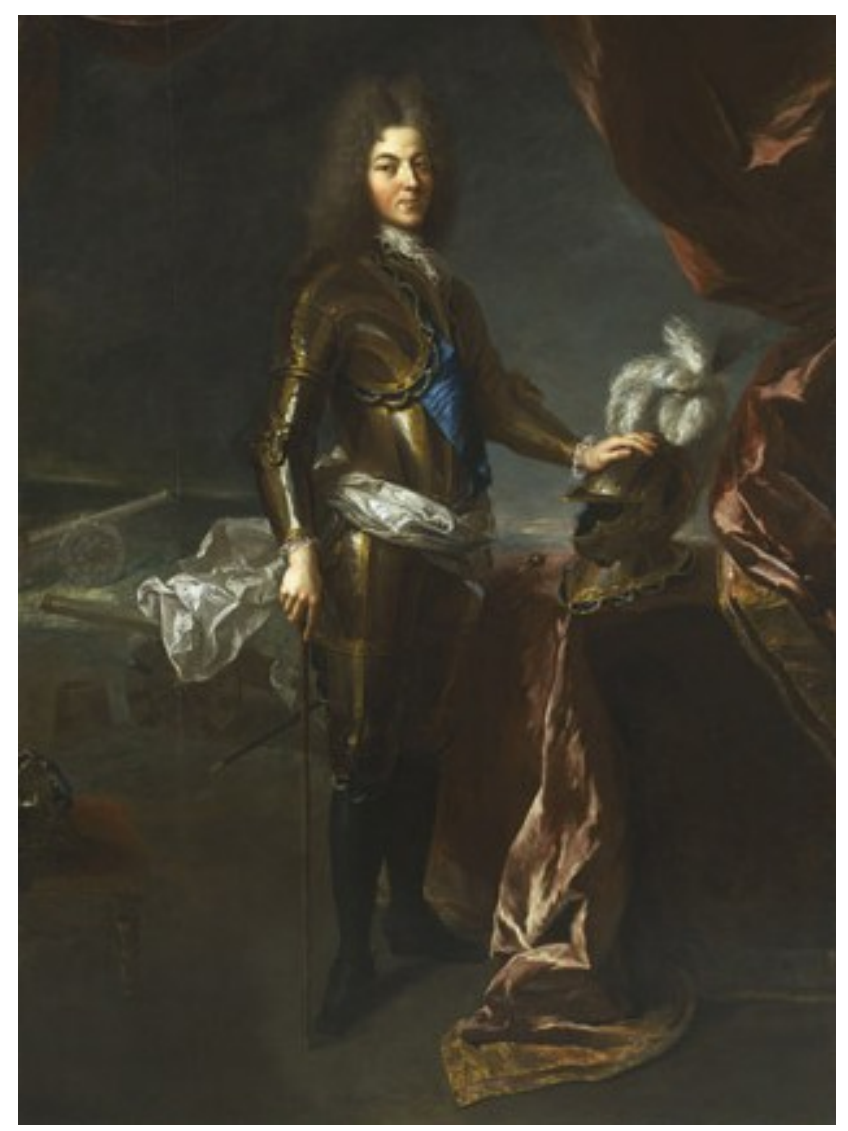

Figure 5. François de Troy. Portrait of Louis-Auguste de Bourbon, duc du Maine. 1715. Oil on canvas. Musée du domaine départemental de Sceaux. Sceaux, France. 


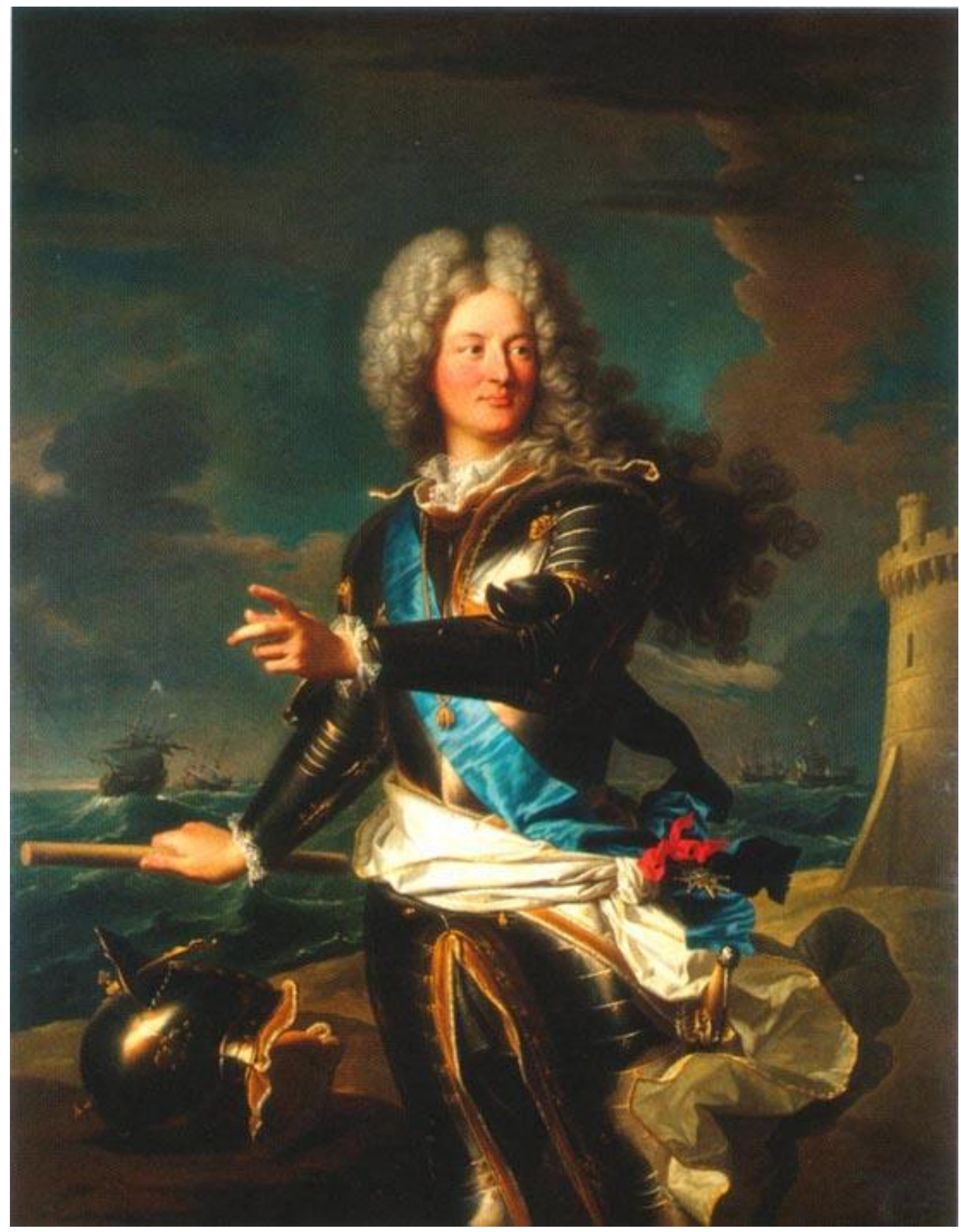

Figure 6. Hyacinthe Rigaud. Portrait of Louis-Alexandre de Bourbon, comte de Toulouse. 1708. Oil canvas. Location unknown. 


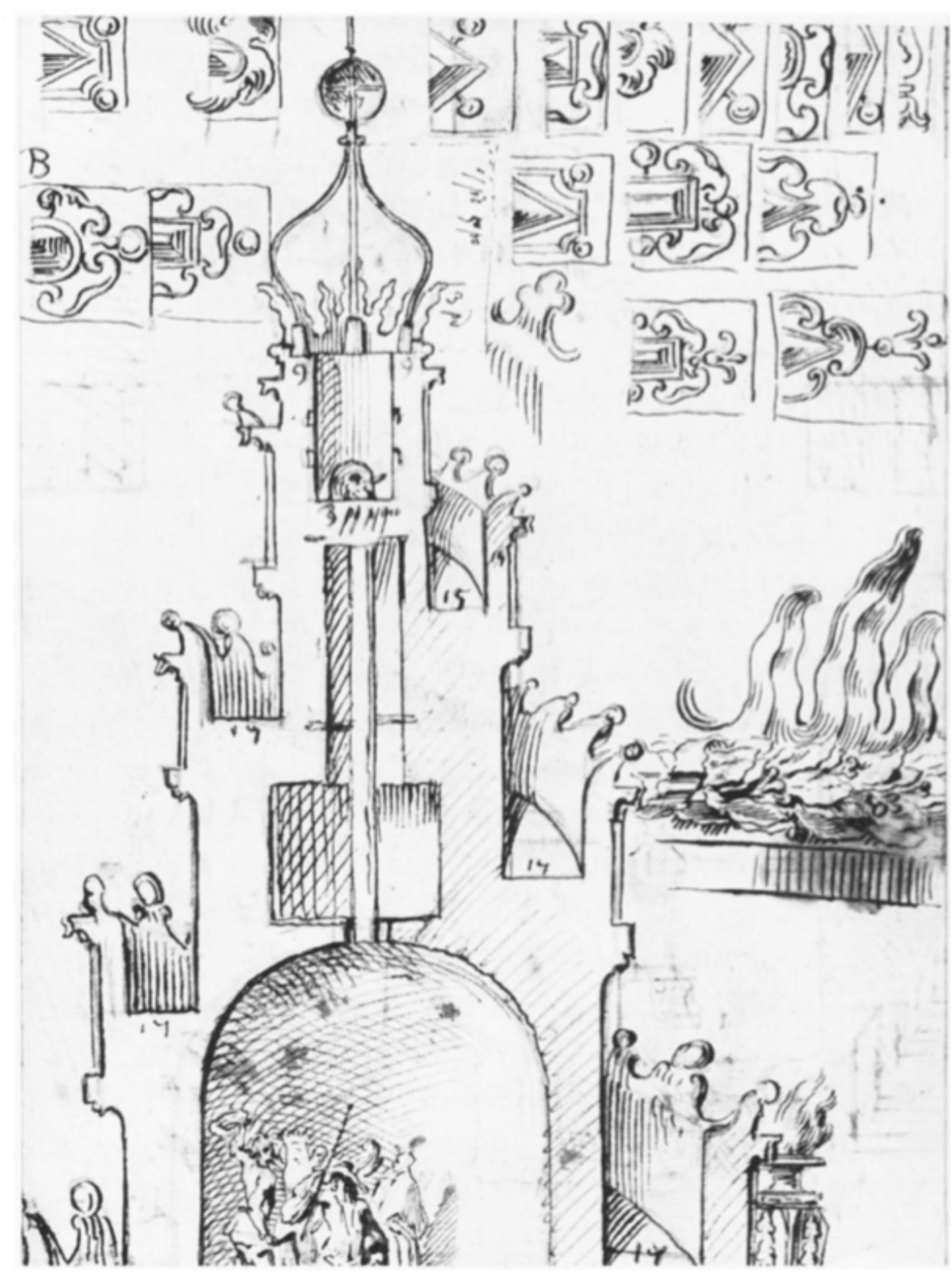

Figure 7.1 Gilles-Marie Oppenord. Section through the spiral of Francesco Borromini's church of Sant' Ivo alla Sapienza, Rome. 1692-1699. Pen and ink on paper. Kunstbibliothek, Berlin. 


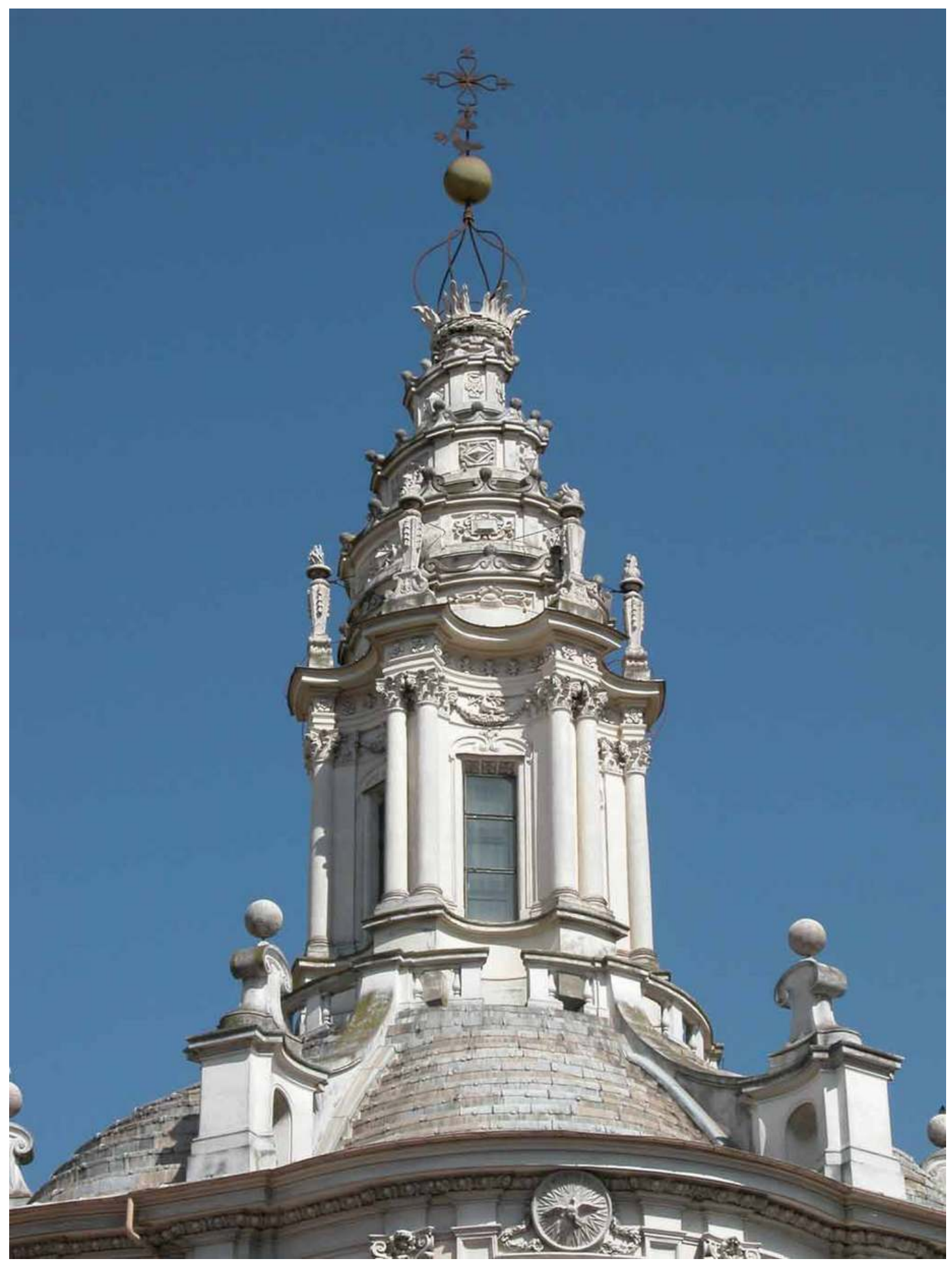

Figure 7.2 Francesco Borromini. Sant'Ivo alla Sapienza, Rome. 1642-1660. Spiral. 


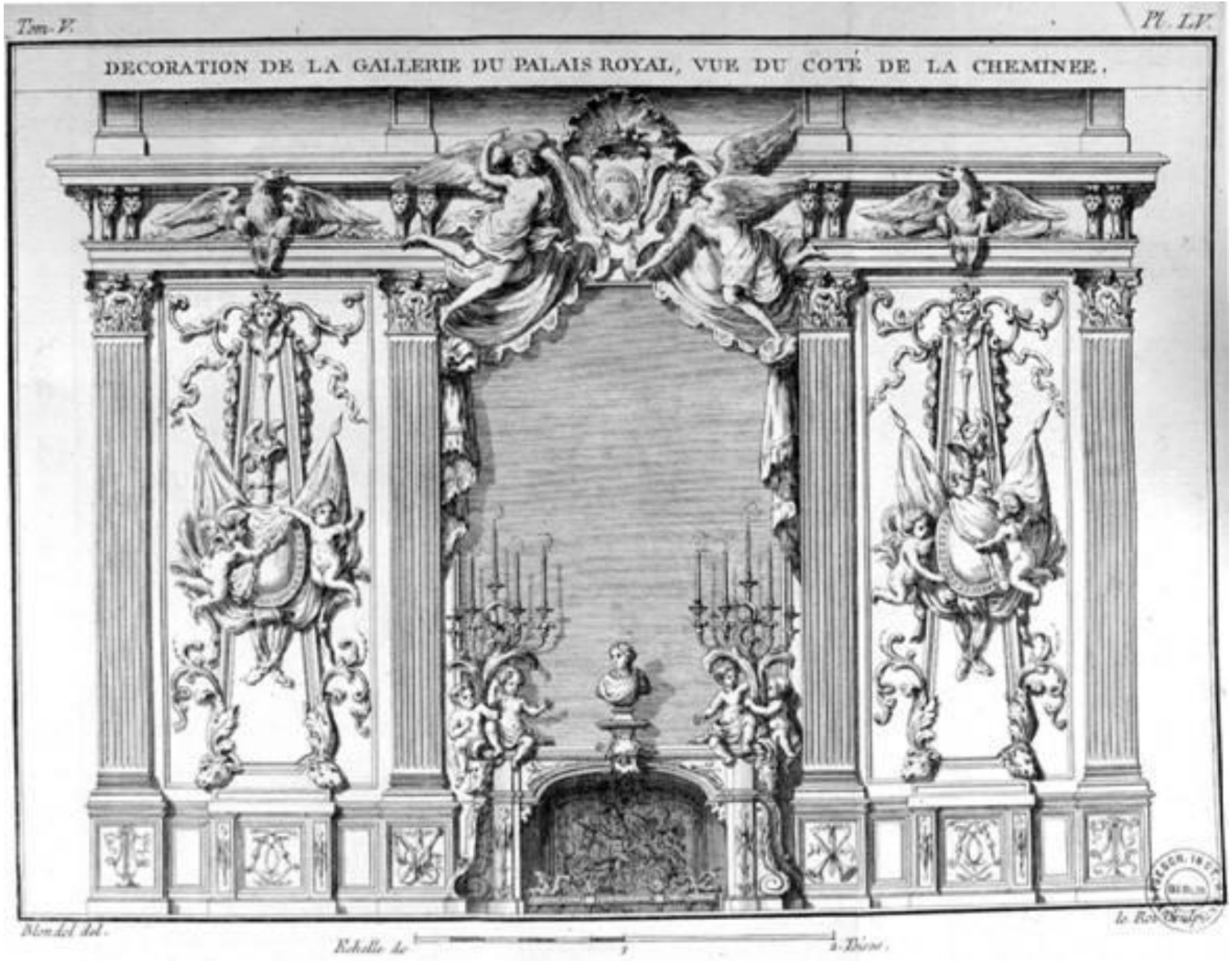

Figure 8. Gilles-Marie Oppenord. North end of the Galérie d'Énée at the Palais-Royal, Paris. ca. 1715-1718. Etching from Jacques-François Blondel, Cours d'architecture. 1771-1777. 


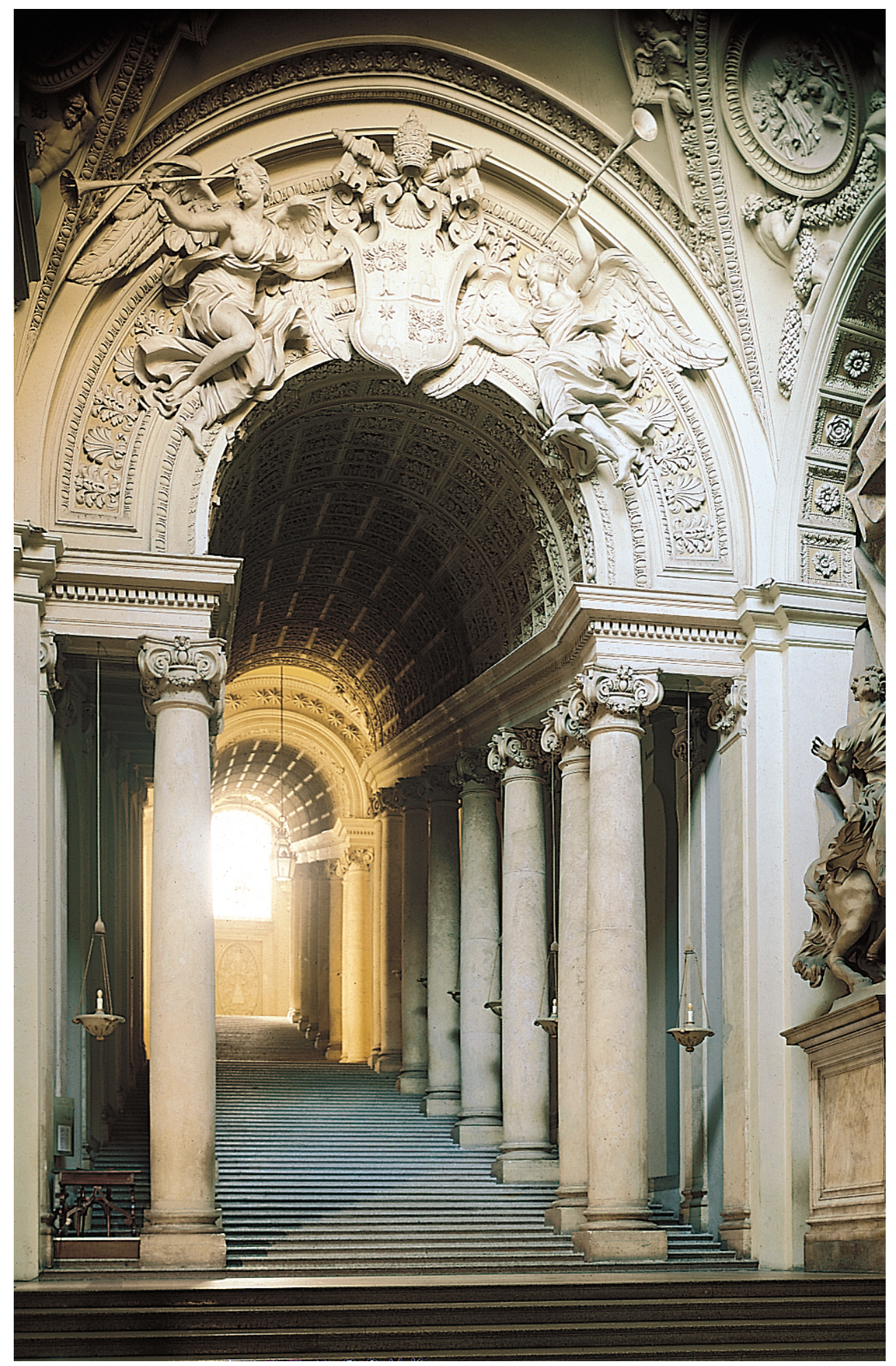

Figure 9. Gian Lorenzo Bernini. Scala Regia, Vatican Palace, Vatican City. 1663-1666. 


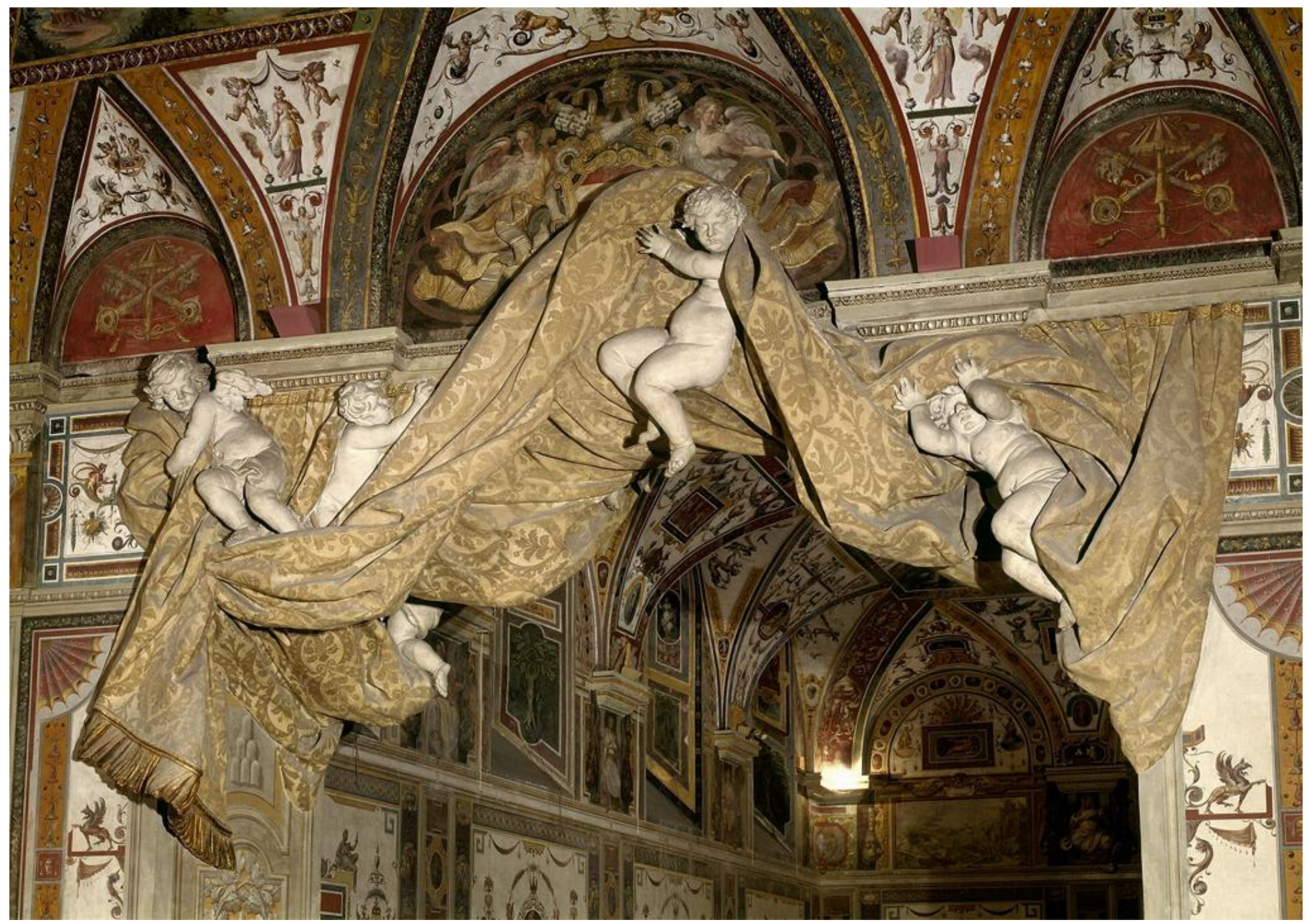

Figure 10. Gian Lorenzo Bernini (designer) and Antonio Raggi (sculptor). Stucco decoration in the Sala Ducale, Vatican Palace, Vatican City. 1656-1657. 


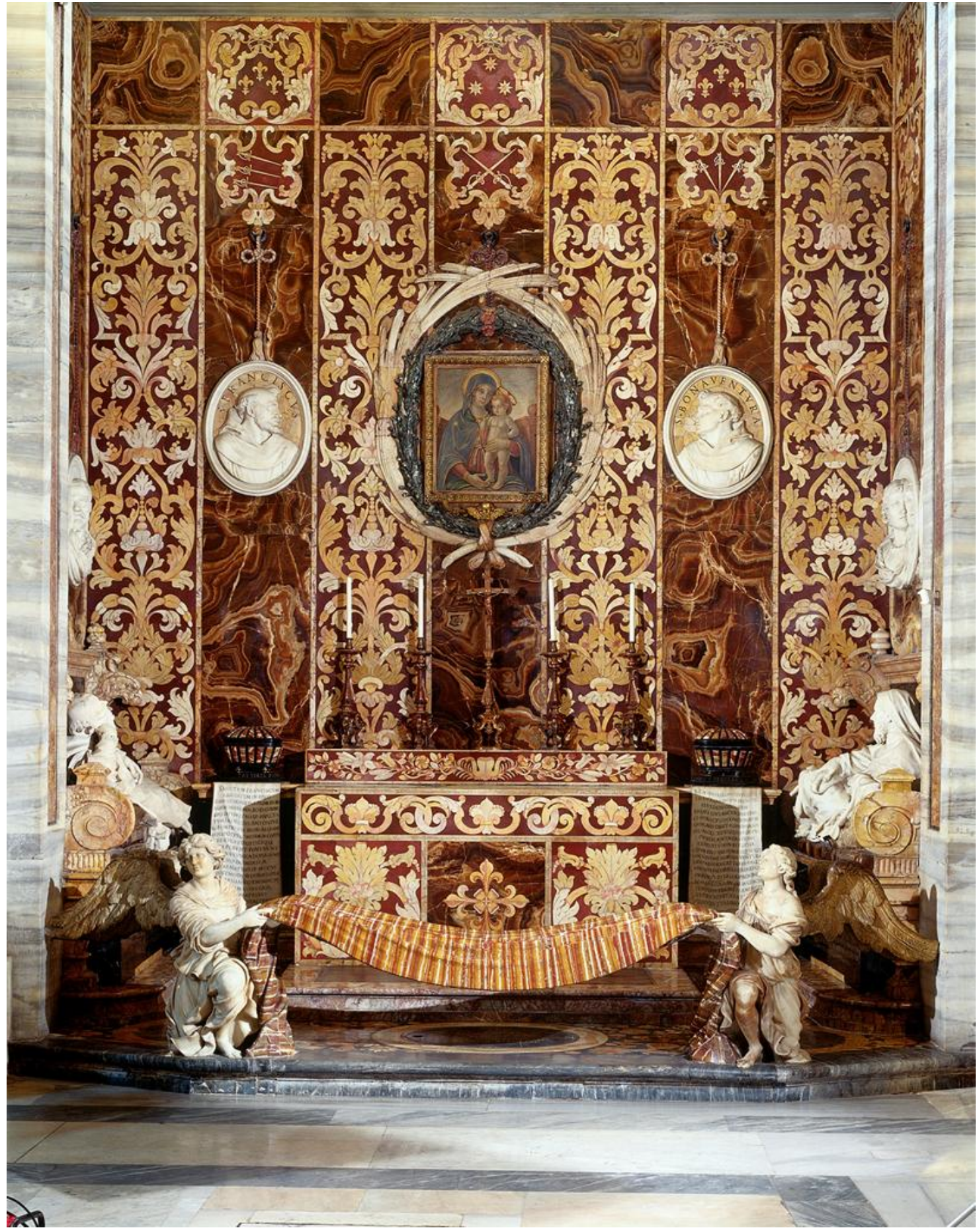

Figure 11. Francesco Borromini. Cappella Spada, San Girolamo della Carità, Rome. ca. 1660. 


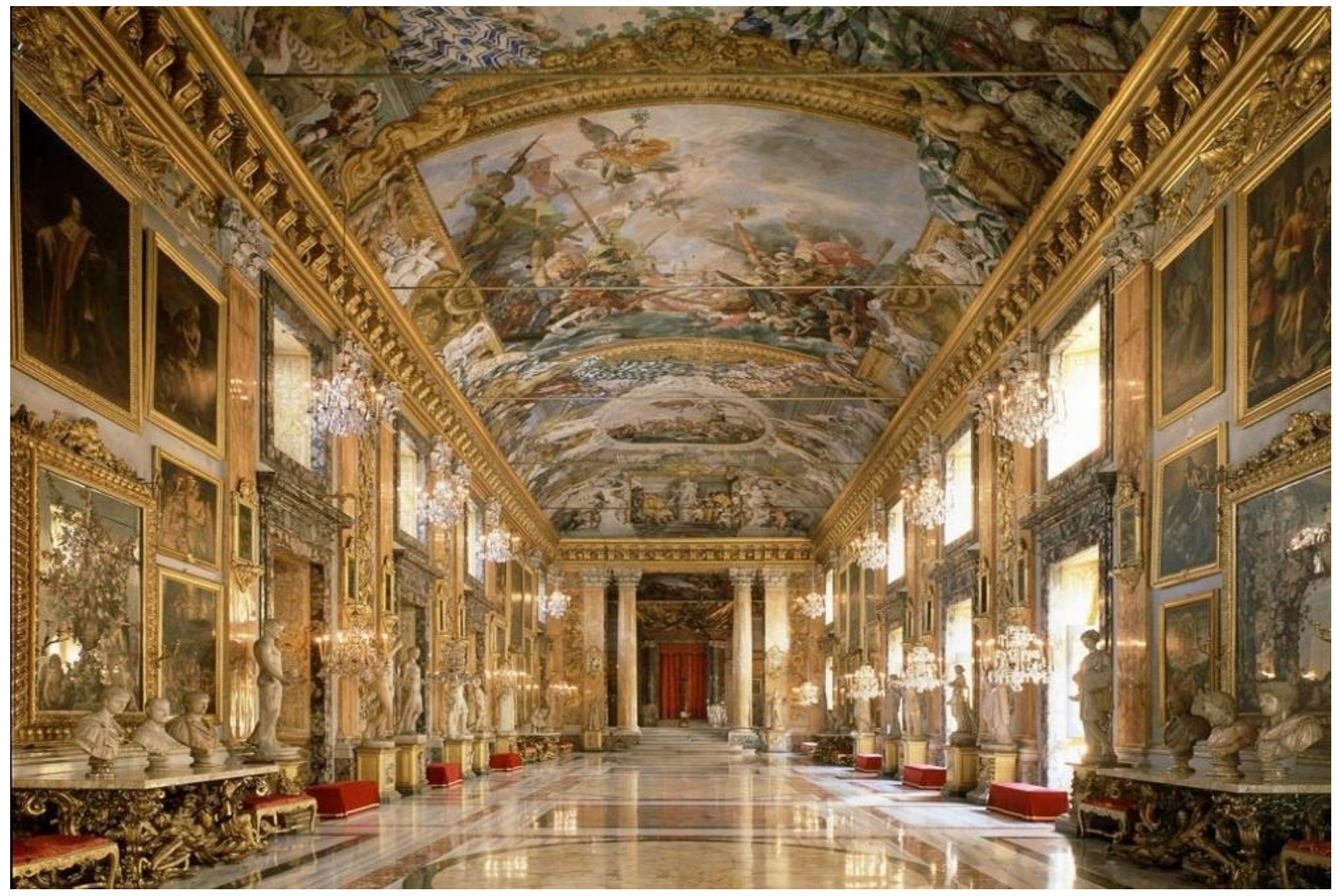

Figure 12. Antonio del Grande (and possibly Gian Lorenzo Bernini), decorated by Giovan Paolo Schor, Giovanni Coli, and Filippo Gherardi. Galleria at the Palazzo Colonna, Rome. 1654-1703. 


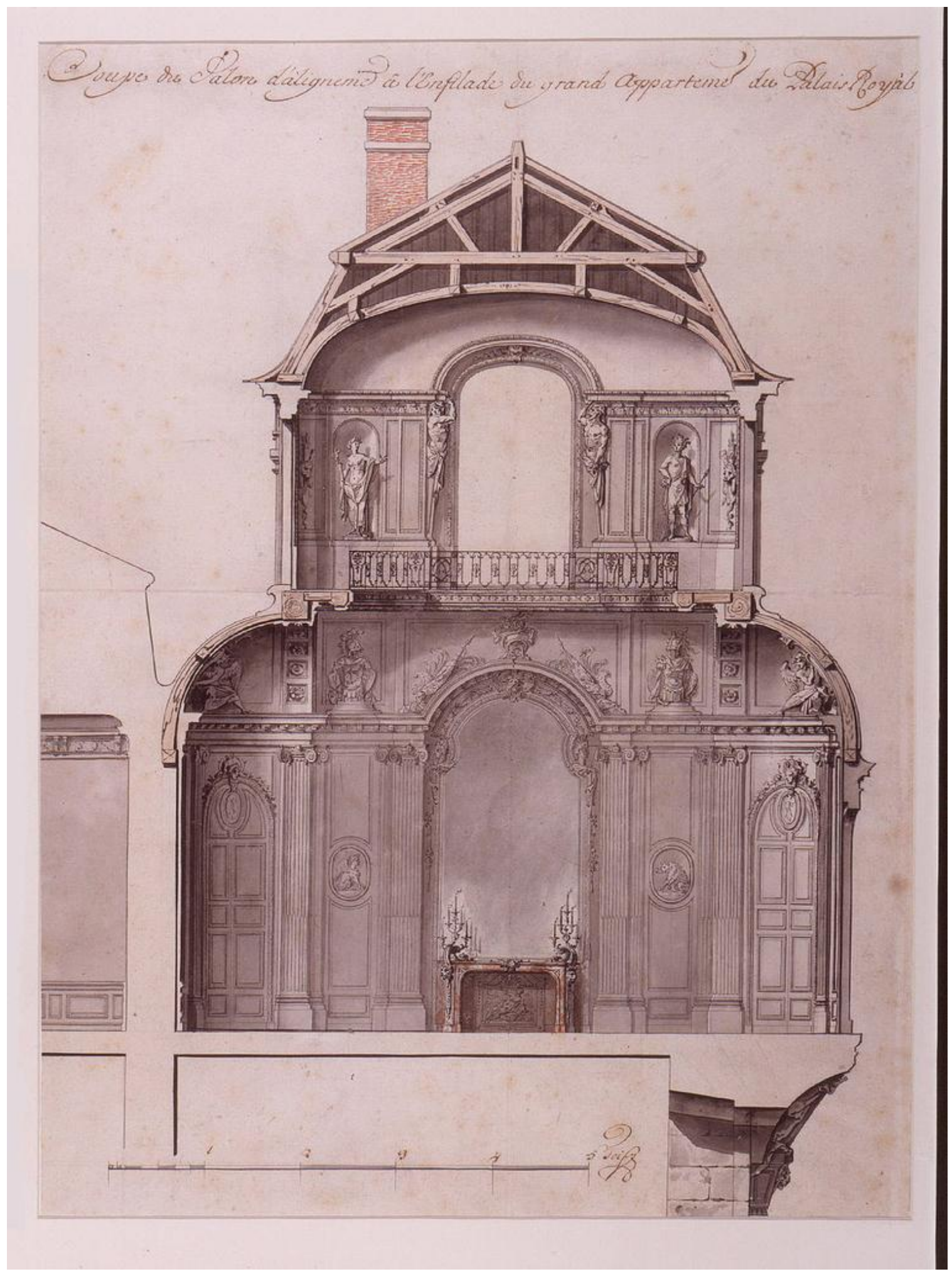

Figure 13. Gilles-Marie Oppenord. Sectional elevation of the Salon d'Angle at the Palais-Royal, Paris. 1719-1721. Pen and black ink, brush and watercolor on white laid paper. Cooper Hewitt, National Design Museum, New York. 


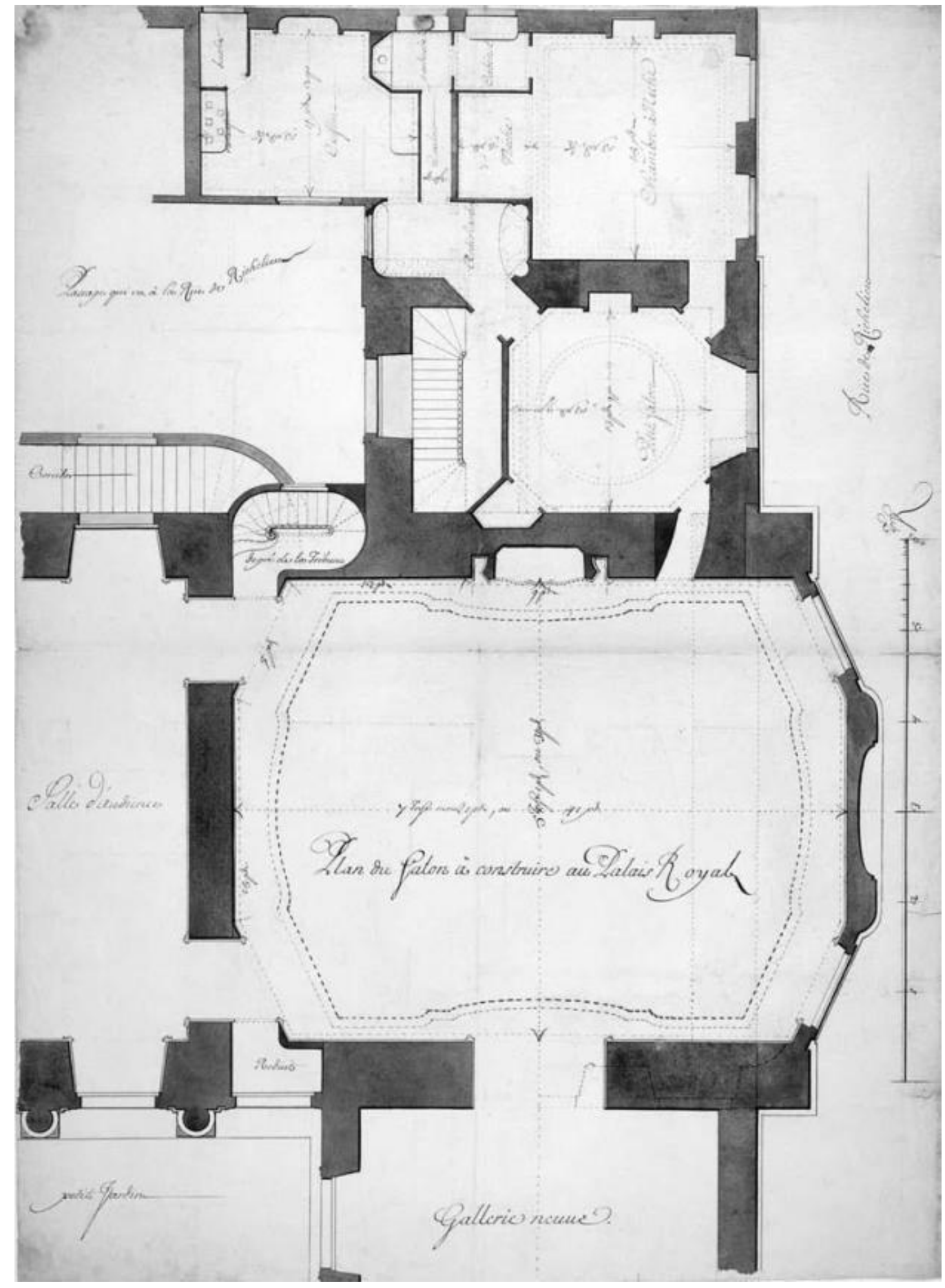

Figure 14. Gilles-Marie Oppenord. Plan of the final scheme for the Salon d'Angle and the petits appartements at the Palais-Royal, Paris. 1719-1721. Pen and black ink with brush and grey, red and pale yellow washes on laid paper. Musée Carnavalet, Cabinet des arts graphiques, Paris. 


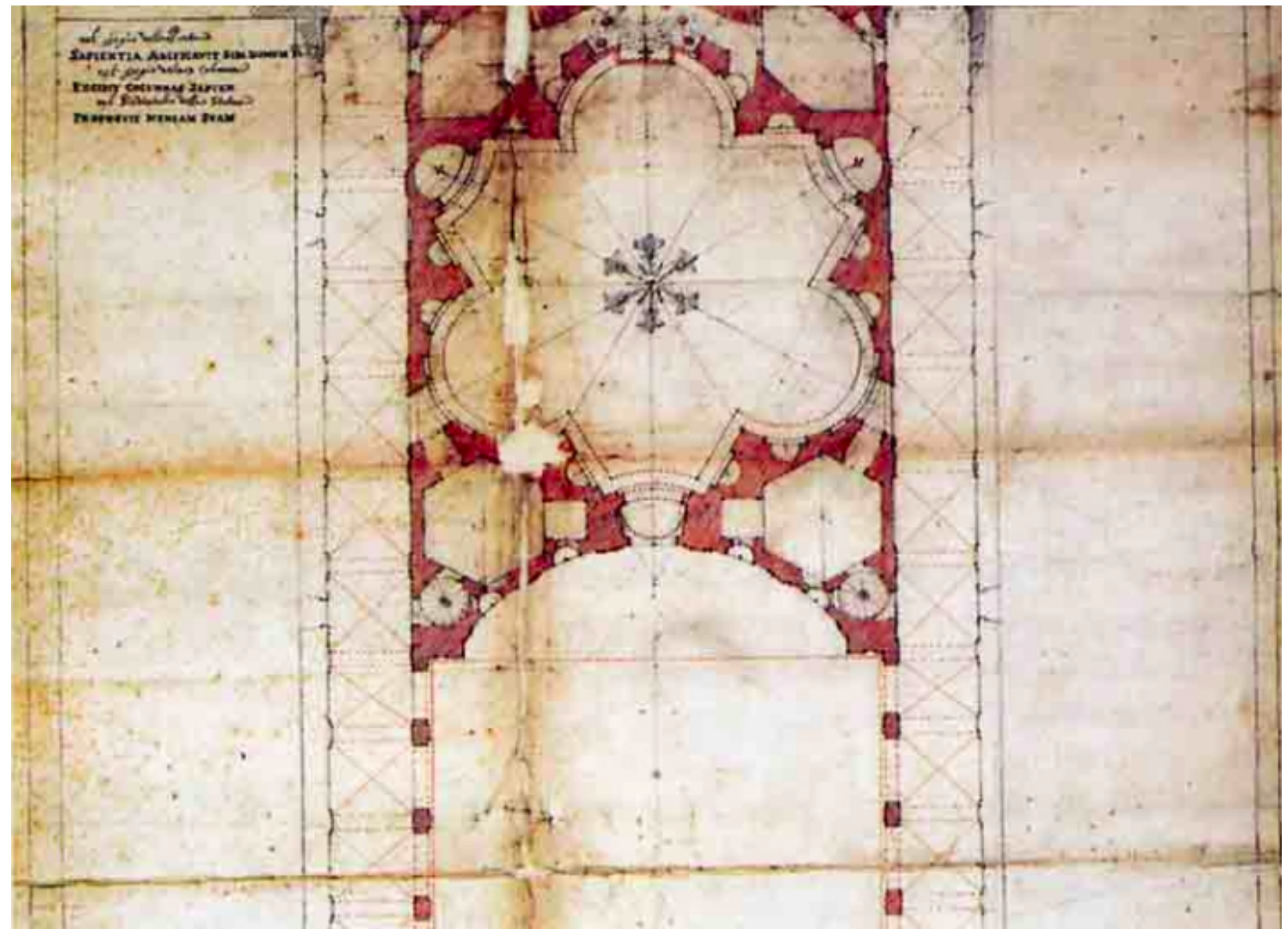

Figure 15. Francesco Borromini. Plan of Sant'Ivo alla Sapienza, Rome. 1642. Pencil and red chalk. Archivio di Stato, Rome. Detail. 


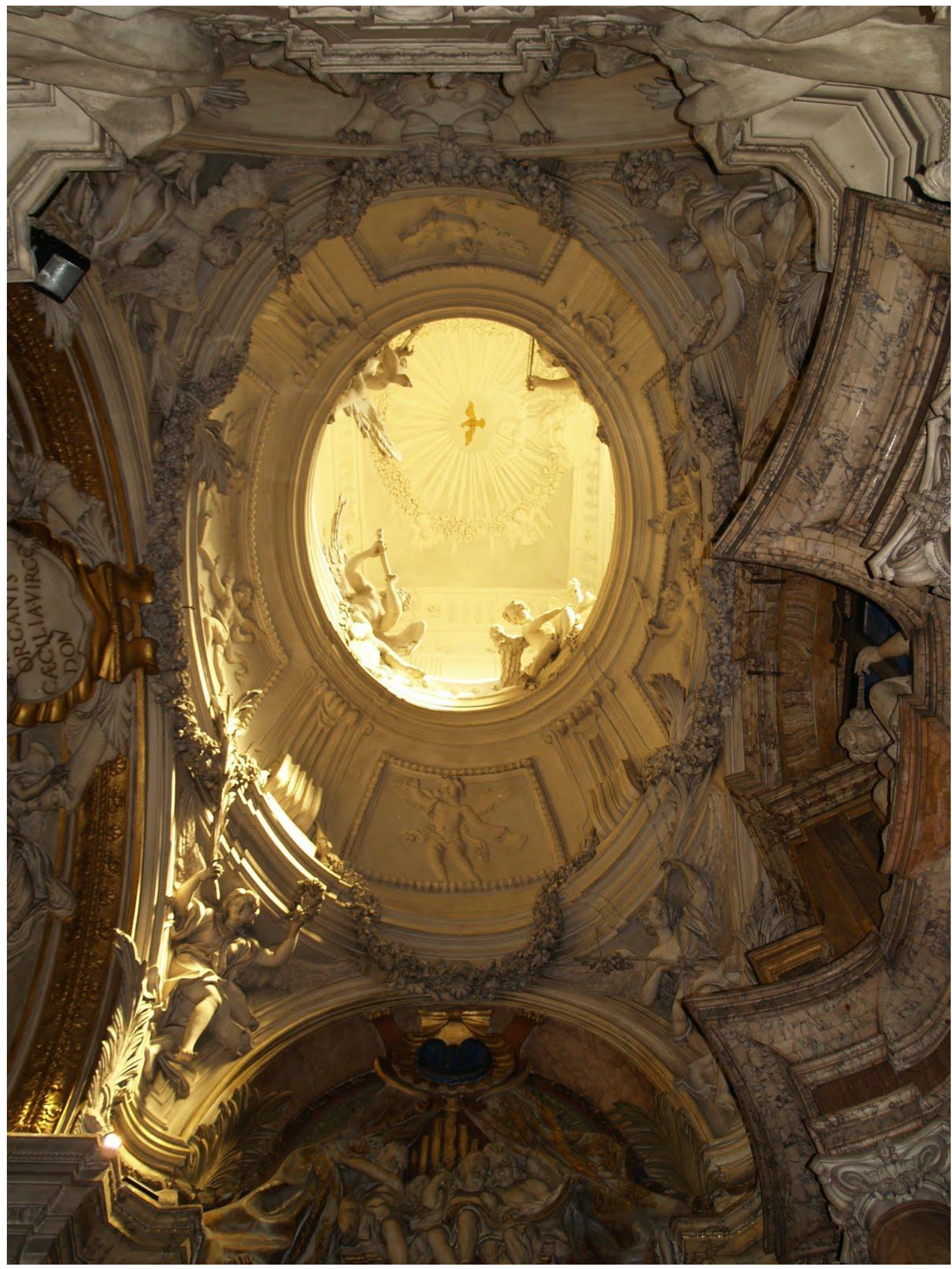

Figure 16. Antonio Gherardi. Interior of the Cappella di Santa Cecilia in the church of San Carlo ai Catinari, Rome. 1691-1700. 


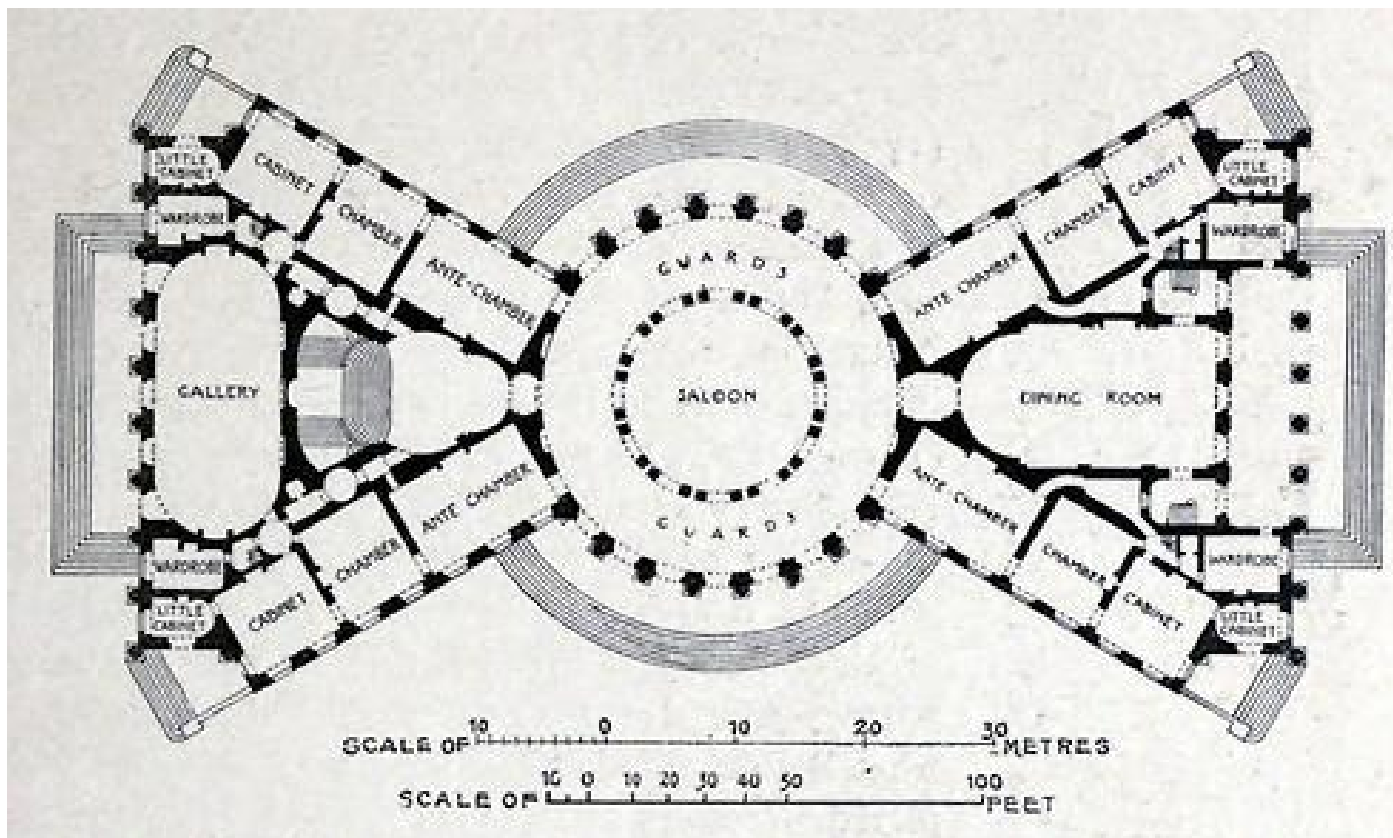

Figure 17. Germain Boffrand. Engraving of the second project for the château de La Malgrange, Jarville (outside of Nancy). ca. 1712.

Figure 18. Gian Lorenzo Bernini. Palazzo Chigi-Odescalchi, Rome. 1664. Etching by Alessandro Specchi. Published in Domenico de' Rossi's Nuovo Teatro delle Fabriche, et Edificii, In Prospettiva di Roma moderna (1699).

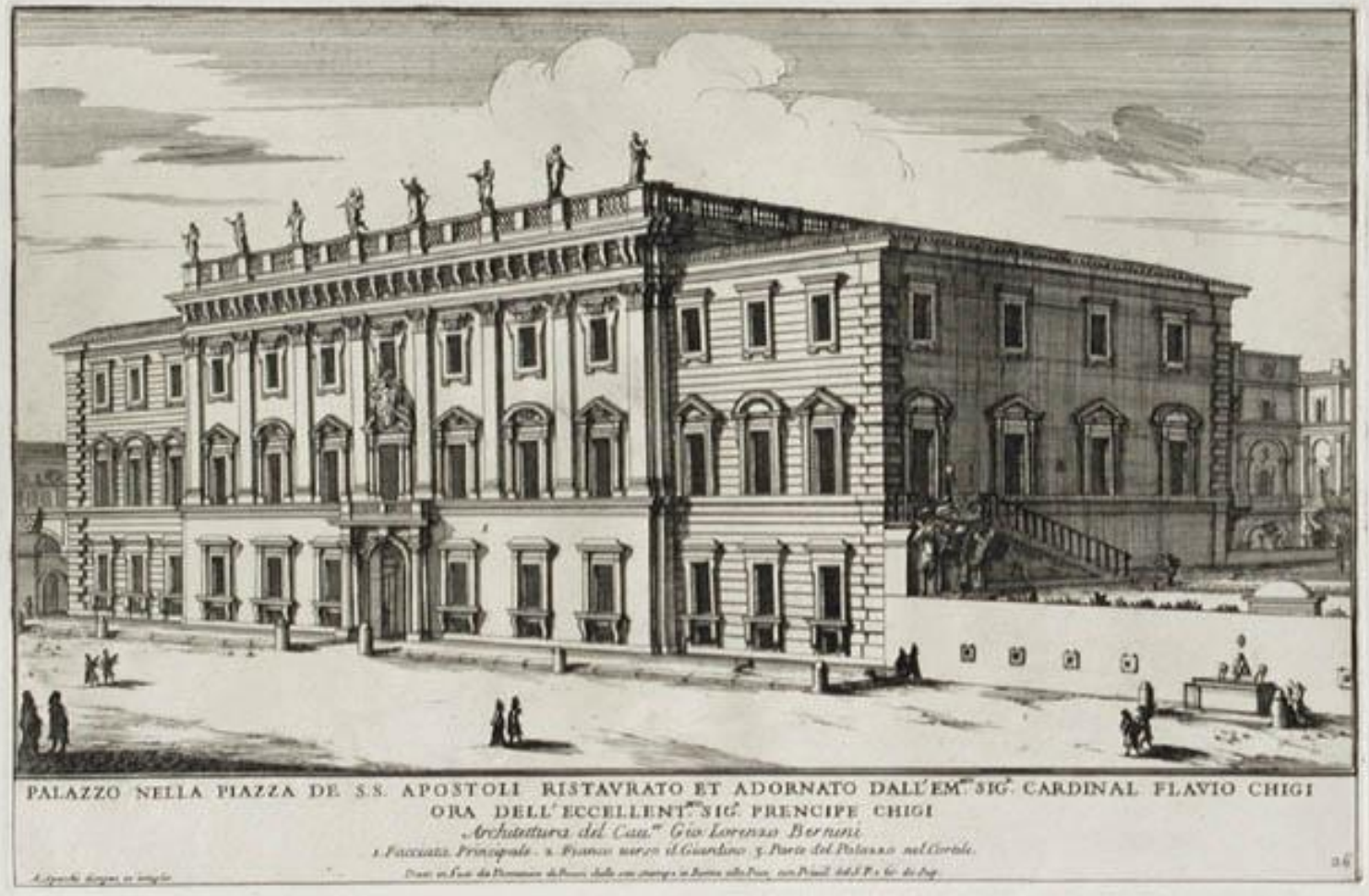


- Faģade de líGêtel de Crion du côté de la Cour.

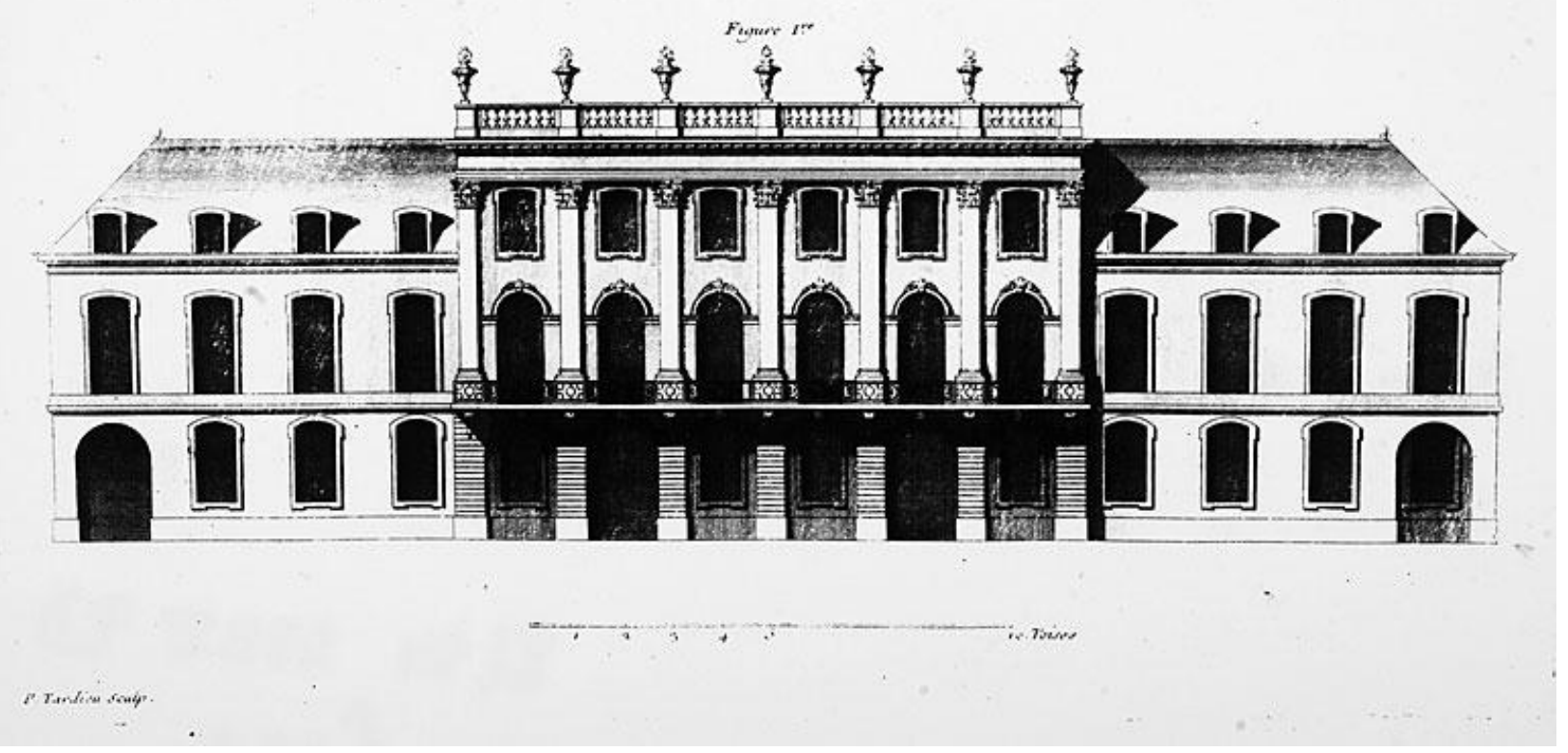

Figure 19. Germain Boffrand. Façade of the Hôtel de Craon, Nancy. ca. 1712. Engraving published in Germain Boffrand's Livre d'Architecture (1715).

Figure 20. Germain Boffrand. Project for the façade of the Palais de l'Arsenal, Paris. ca. 1715. Bibliothèque nationale de France, Paris.

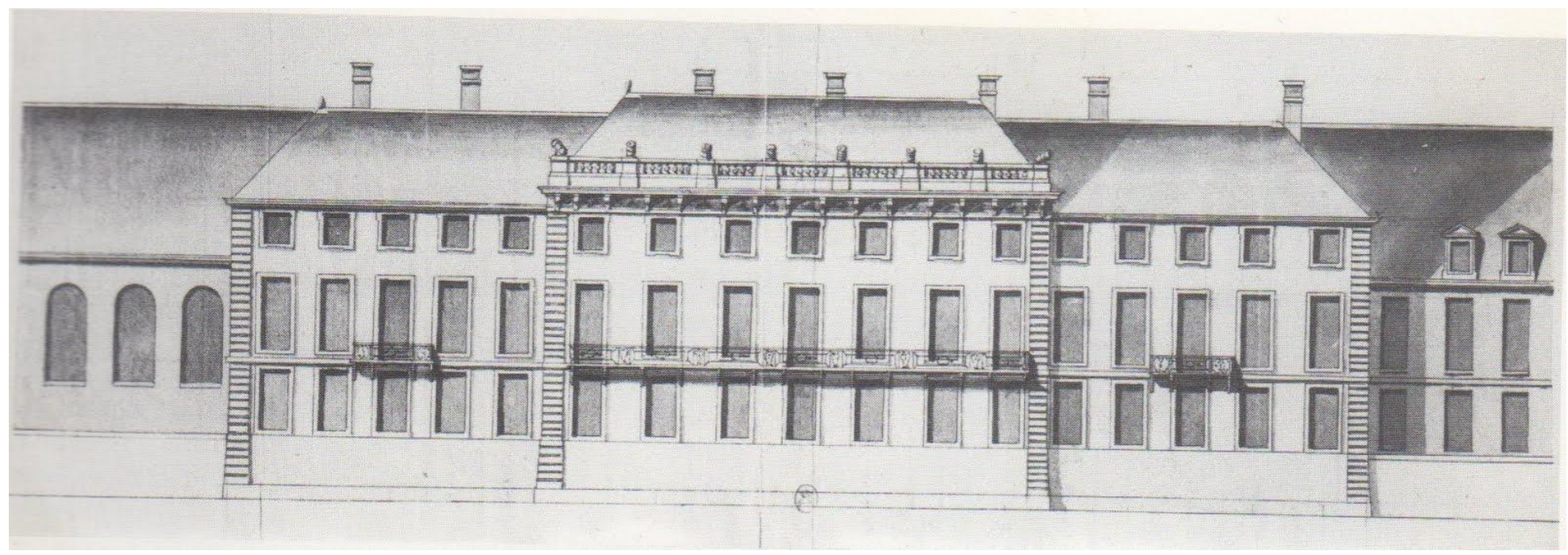




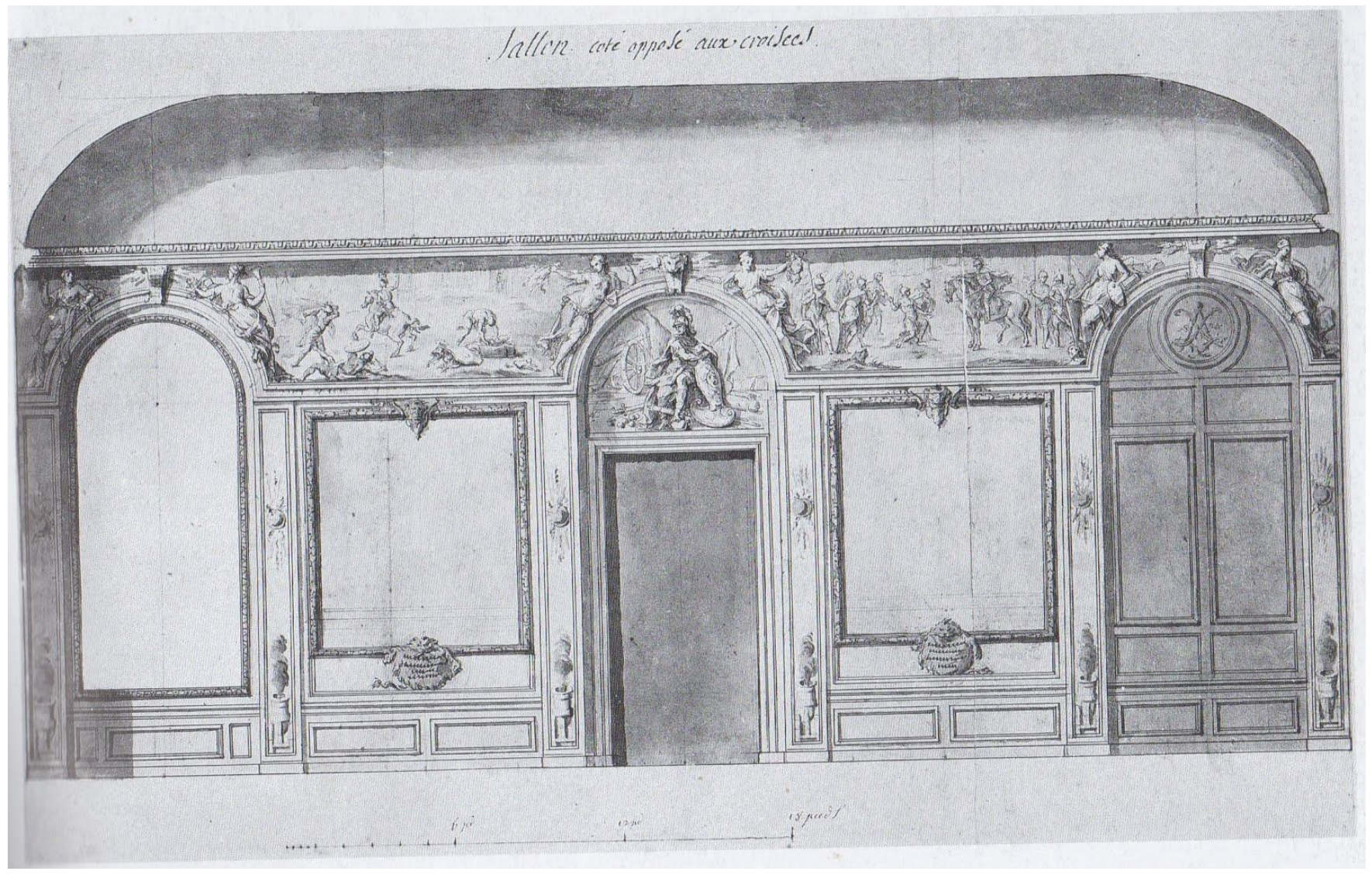

Figure 21. Germain Boffrand. Project for the interior of the salon of the Palais de l'Arsenal, Paris. ca. 1715. Pen and ink with wash. Kunstbibliothek, Berlin. 


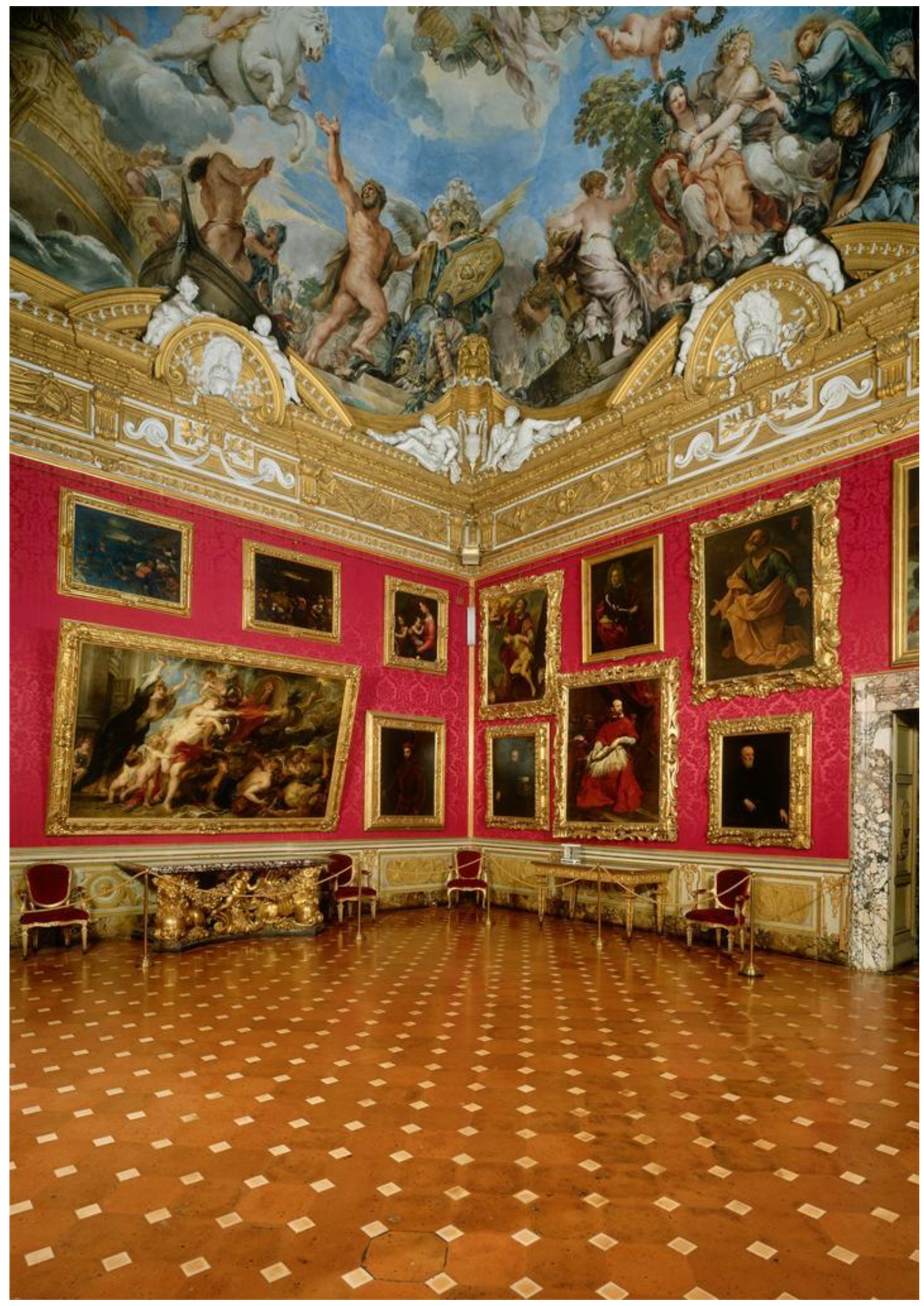

Figure 22. Pietro da Cortona. Sala di Marte, Palazzo Pitti, Florence. 1645-1647. 


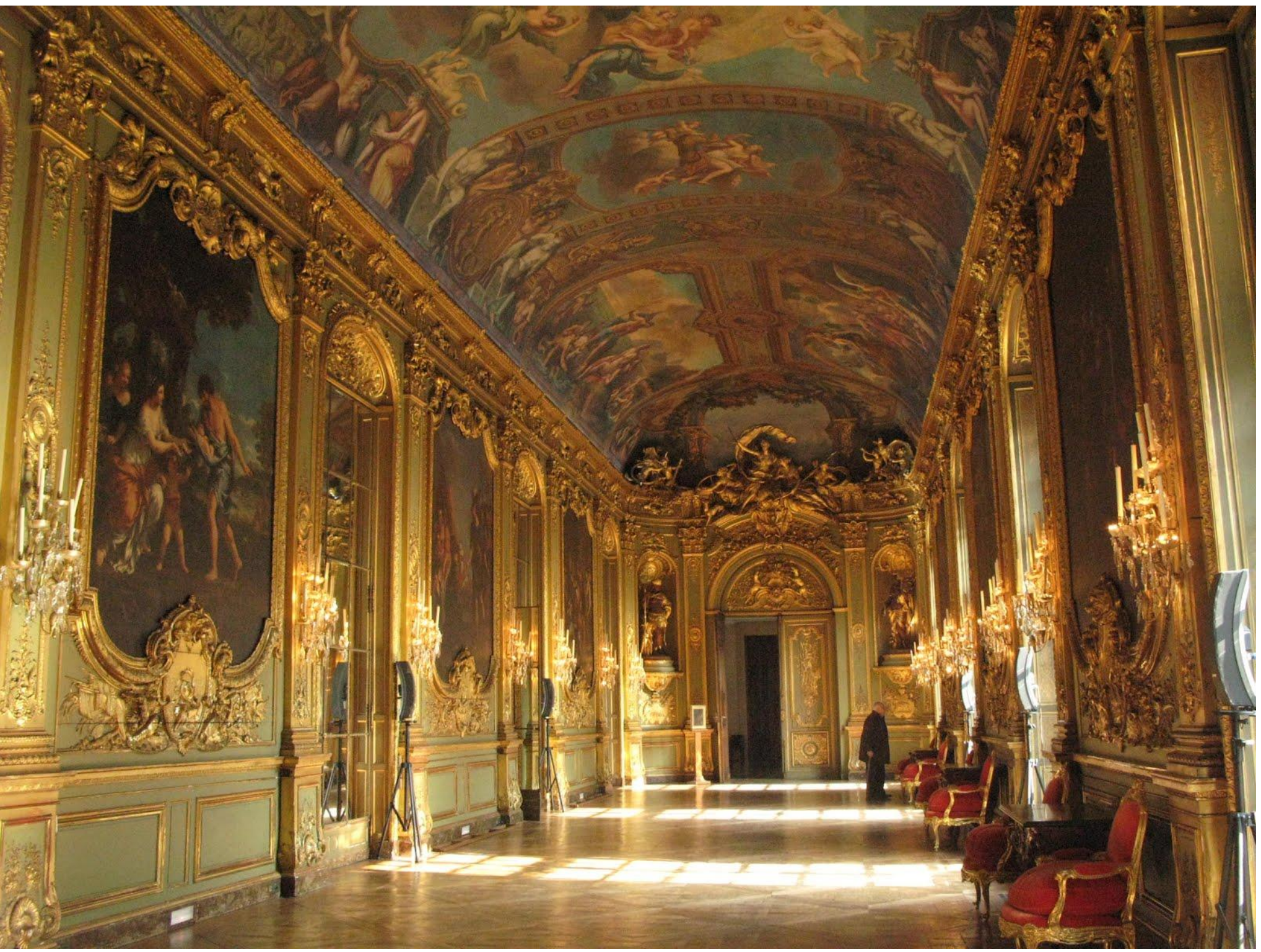

Figure 23. Robert de Cotte (architect) and François-Antoine Vassé (decorator). Galérie Dorée at the Hôtel de Toulouse, Paris. ca. 1718. 


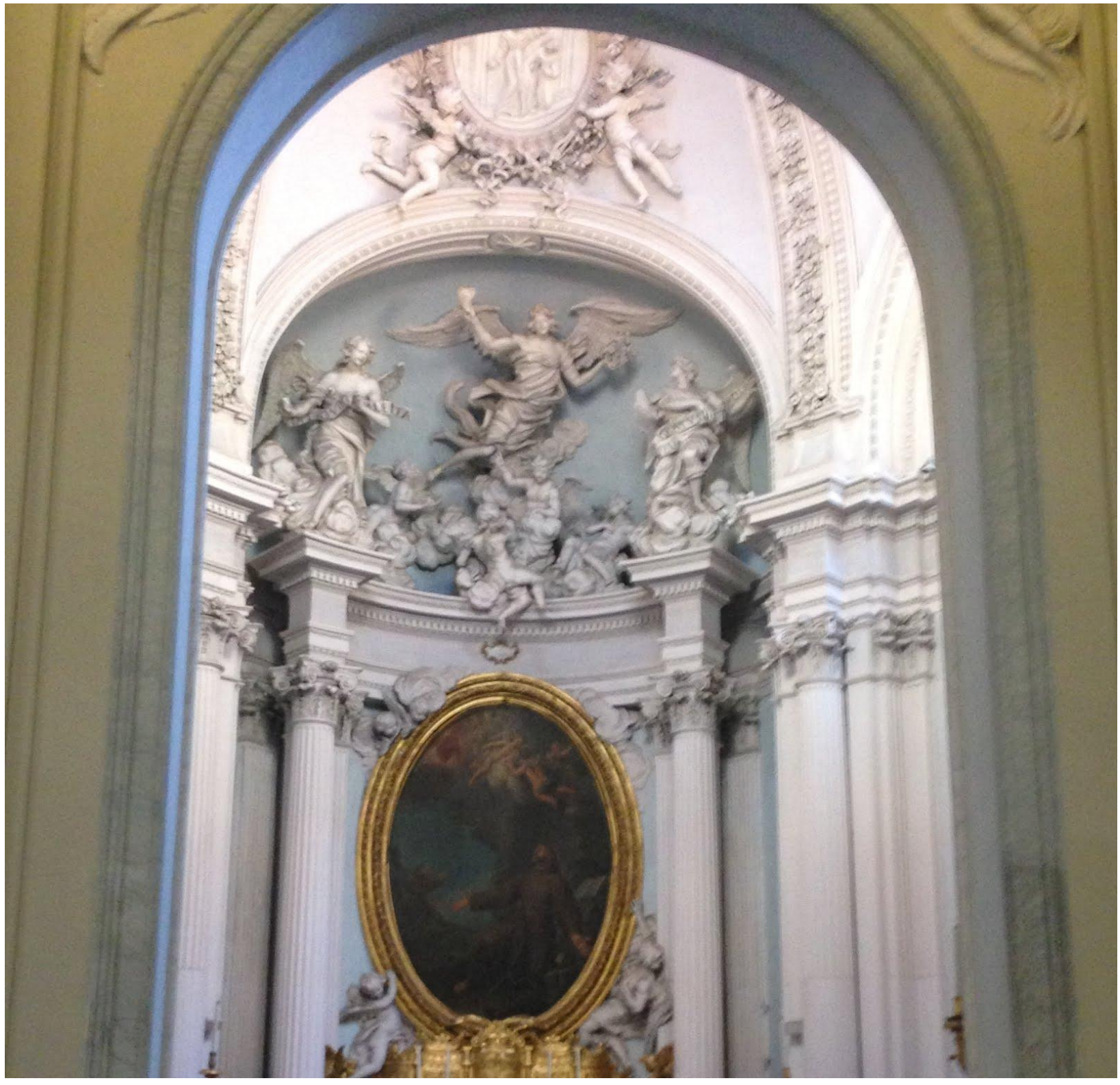

Figure 24. Filippo Carcani. Stucco decoration in the Cappella Lancellotti, San Giovanni in Laterano, Rome. ca. 1685. 


\section{BIBLIOGRAPHY}

Babelon, Jean-Pierre. "Le palais de l'Arsenal à Paris: étude architecturale et essai de répertoire iconographique critique." Bulletin Monumental 128 (1970): 267-310.

Bédard, Jean-François. "Political Renewal and Architectural Revival during the French Regency: Oppenord's Palais-Royal." Journal of the Society of Architectural Historians 68, no. 1 (March 2009): 30-51.

. Decorative Games: Ornament, Rhetoric, and Noble Culture in the Work of GillesMarie Oppenord (1672-1742). Newark: University of Delaware Press, 2011.

Berger, Robert W. Antoine Le Pautre: A French Architect of the Era of Louis XIV. New York: New York University Press, 1969.

Bernot, Jacques. Mademoiselle de Nantes, fille préférée de Louis XIV. Paris: Nouvelles Editions Latines, 2004.

Blondel, Jacques-François. Cours d'architecture, ou Traité de la décoration, distribution et construction des bâtiments contenant les leçons données en 1750, et les années suivantes. Vol. 1. Paris: Desaint, 1771.

Blunt, Anthony, ed. Baroque and Rococo Architecture and Decoration. New York: Harper and Row, 1978.

Art and Architecture in France, 1500-1700. 5th ed. New Haven, CT: Yale University Press, 1999.

Brice, Germain. Nouvelle description de la ville de Paris, et de tout ce qu'elle contient de plus remarquable. Vol. 1. Paris: J. M. Gandouin, 1725.

Burke, Peter. The Fabrication of Louis XIV. New Haven, CT: Yale University Press, 1992.

Caplan, Jay. In the King's Wake: Post-Absolutist Culture in France. Chicago: University of Chicago Press, 1999.

Dézallier d'Argenville, Antoine-Nicolas. Vies Des Fameux Architectes Depuis La Renaissance Des Arts, Avec La Description De Leurs Ouvrages. Vol. 1. Paris: Debure, 1787.

Duggan, Anne E. Salonnières, Furies, and Fairies: The Politics of Gender and Cultural Change in Absolutist France. Newark: University of Delaware Press, 2005. 
Gallet, Michel, and Jörg Garms, eds. Germain Boffrand, 1667-1754: L'aventure d'un architecte indépendant. Paris: Herscher, 1986.

Garms, Jörg. "Boffrand.” In Gallet and Garms, 22-142.

Grönert, Alexander. "Domenico de' Rossi." In Architectural Theory: From the Renaissance to the Present, 148-55. Cologne: Taschen, 2003.

Hills, Helen, ed. Rethinking the Baroque. Farnham, UK: Ashgate, 2011.

Hurt, John J. Louis XIV and the Parlements: The Assertion of Royal Authority. Manchester, UK: Manchester University Press, 2002.

James, Alan. The Origins of French Absolutism, 1598-1661. Seminar Studies in History. Abingdon, UK: Routledge, 2013.

Kimball, Fiske. The Creation of the Rococo. New York: Norton Library, 1964.

Ladurie, Emmanuel Le Roy. Saint-Simon and the Court of Louis XIV. Translated by Arthur Goldhammer. Chicago: University of Chicago Press, 2001.

Pérouse de Montclos, Jean-Marie. Histoire de l'architecture française: De la Renaissance à la Révolution. Paris: Mengès, 1989.

Pons, Bruno. “Germain Boffrand et le Décor Intérieur.” In Gallet and Garms, 187-252.

Saint-Simon, Louis de Rouvroy, duc de. Mémoires complets et authentiques du duc de SaintSimon sur le siècle de Louis XIV et la Régence: 1691-1723. Edited by Adolphe Chéruel. Vol. 10. Paris: Hachette, 1857.

Scott, Katie. The Rococo Interior: Decoration and Social Spaces in Early Eighteenth-Century Paris. New Haven, CT: Yale University Press, 1995.

Smith, Gil R. Architectural Diplomacy: Rome and Paris in the Late Baroque. Cambridge: Massachusetts Institute of Technology Press, 1993.

Smith, Jay M. The Culture of Merit: Nobility, Royal Service, and the Making of Absolute Monarchy in France, 1600-1789. Ann Arbor: University of Michigan Press, 1996.

Tadgell, Christopher. "France." In Blunt, Baroque and Rococo Architecture and Decoration, 106-42. 
Tapié, Victor-Lucien. The Age of Grandeur: Baroque Art and Architecture. Translated by A. Ross Williamson. 2nd ed. New York: Frederick A. Praeger, 1966.

Wittkower, Rudolf. Art and Architecture in Italy, 1600-1750. 6th ed. 3 vols. New Haven, CT: Yale University Press, 1999.

Wölffllin, Heinrich. Renaissance and Baroque. Translated by Kathrin Simon. London: William Collins Sons, 1964.

Ziskin, Rochelle. Sheltering Art: Collecting and Social Identity in Early Eighteenth-century Paris. University Park: Pennsylvania State University Press, 2012. 